Chapter 5

\title{
The Possibility of Future Biofuels Production Using Waste Carbon Dioxide and Solar Energy
}

\author{
Krzysztof Biernat, Artur Malinowski and \\ Malwina Gnat \\ Additional information is available at the end of the chapter \\ http://dx.doi.org/10.5772/53831
}

\section{Introduction}

The Earth's energy requirements are estimated at 14 TW/ y. Considering the economic development, and therefore high consumption and constantly increasing number of people in the world, it is estimated that energy demand in 2050 will be amount 28 - 30 TW/ y. Fuels from crude oil supply about $96 \%$ of the worldwide energy demand for transport. On the other hand, known petroleum reserves are limited and will eventually run out. According to preliminary calculations, fossil fuels will be exhausted within 150-200 years. Fuel consumption causes the emission of carbon dioxide into the atmosphere, resulting in the collapse of the balance between carbon dioxide released to environment, and gas that can be absorbed by plants. It is estimated, that in case of continued use of traditional energy sources by 2030, carbon dioxide levels will rise to 40 billion $\mathrm{Mg}$ per year. The correlation of carbon dioxide emissions from the world's population is shown in Figure 1:

Global emissions of $\mathrm{CO}_{2}$ and other GHGs, despite commitments of the reduction made by developed countries, will continue to grow, because of increasing production in developing countries, for which clean technologies and investing in renewable energy sources are too expensive. Currently, such a trend can be observed, because the developed countries carbon dioxide emissions was reduced by $6.5 \%$ (according to IEA [2] data for 2009). On the other hand the developing countries increased the emissions up to 3.3\% (mainly in Asia and the Middle East). In this way, the twenty-first century economy will be depend on fossil fuel resources. As a consequence of this state, GHG concentrations will increase, resulting in the continued progress of global warming. Club of Rome, in 1972, has presented a report: "The Limits to Growth" which predicted that before 2072, present industrial civilization will collapse, as a result of the lack of available energy resources, or because of polluted environment. 


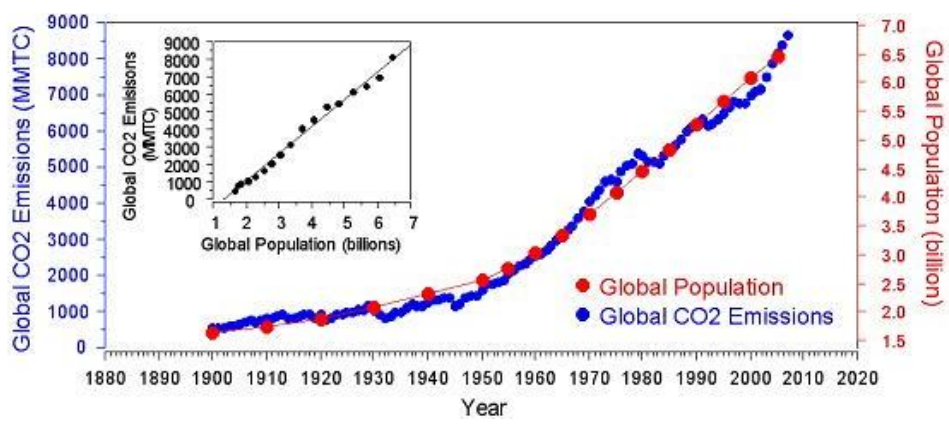

Figure 1. The correlation of $\mathrm{CO}_{2}$ emissions with the world's population [1]

It is important to get alternative energy sources, that will be able increasingly replace the fossil fuels with reducing effect of carbon dioxide emissions at the same time. That may be renewable energy sources (RES), such as wind, water, geothermal or solar energy. The potential of the solar energy is estimated up to $100.000 \mathrm{TW} / \mathrm{y}$. This huge amount of energy has high potential of application in thermochemical biomass conversion or artificial photosynthesis for processing carbon dioxide and water into the organic compounds.

\section{Solar radiation as an energy source}

Solar energy is the most important source of the energy used on the Earth. According with hypothesis of $\mathrm{H}$. Bethe and C. Weizsacker made in 1938 - the energy of the Sun, has its source in the fusion reactions that occur in the interior, according to the reaction (1): [3]

$$
4{ }^{1} \mathrm{H} \rightarrow{ }^{4} \mathrm{He}+2 \mathrm{e}^{+}+2 v_{\mathrm{e}}+\mathrm{E}
$$

Solar radiation is in the form of a wide band of the electromagnetic spectrum, which is shown in Figure 2. It covers wavelengths from about $250 \mathrm{~nm}$ to $1000 \mathrm{~nm}$ over [4].

However, the full spectral range of solar radiation (including the ultraviolet (UV)) reaches only to the edge of Earth's atmosphere. The total energy that reaches the Earth's atmosphere is marked as Fs - a stream of sunlight that the average power is $1368 \mathrm{~W} / \mathrm{m}^{2}$. Some of the radiation wavelength, passing through the layers of the Earth's atmosphere, are absorbed by the molecules. Even at the height of the Kármán line (about $100 \mathrm{~km}$ above sea level) there is the first interaction of solar radiation with occurring nitrogen and oxygen. Ultraviolet (UV), at a wavelength below $280 \mathrm{~nm}$, is high-energy radiation. The energy is enough to cause dissociation of molecules into atoms as is shown in following equations 2 and 3:

$$
\mathrm{N}_{2}+\mathrm{hv}(\lambda \approx 126 \mathrm{~nm}) \rightarrow 2 \mathrm{~N} \quad \Delta \mathrm{H}^{\circ}=945 \mathrm{~kJ} / \mathrm{mol}
$$




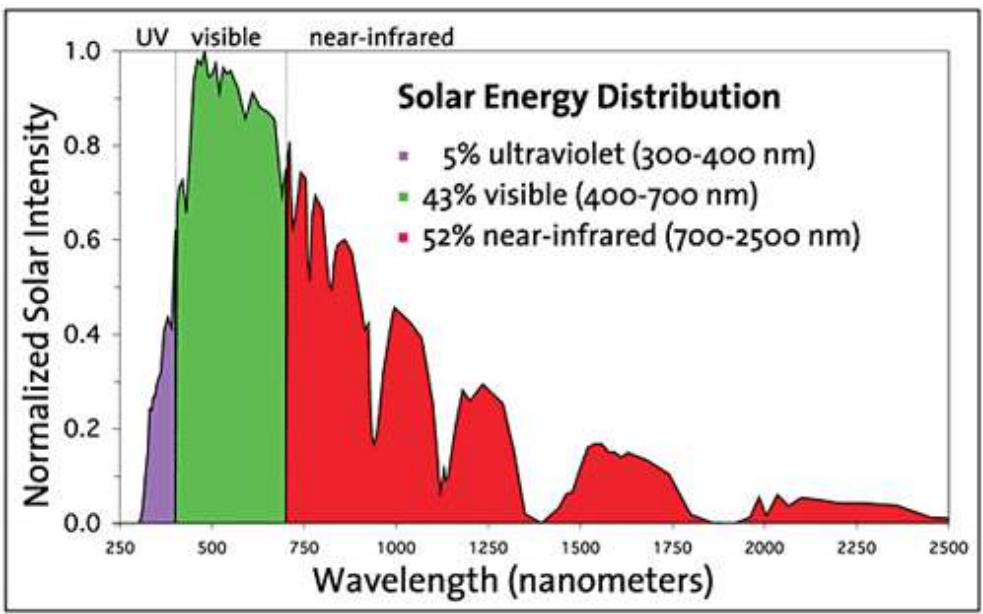

Figure 2. The spectrum of solar radiation [5]

$$
\mathrm{O}_{2}+\mathrm{hv}(\lambda \approx 240 \mathrm{~nm}) \rightarrow 2 \mathrm{O} \quad \Delta \mathrm{H}^{\circ}=498 \mathrm{~kJ} / \mathrm{mol}
$$

In the lower layer of the atmosphere - called the ionosphere - solar energy is absorbed by the reactions occurring in the ionization of chemical individuals (reactions 4 and 5).

$$
\begin{array}{cc}
\mathrm{N}_{2}+\mathrm{hv}(\lambda \approx 80 \mathrm{~nm}) \rightarrow 2 \mathrm{~N}^{+}+\mathrm{e} & \Delta \mathrm{H}^{\circ}=1500 \mathrm{~kJ} / \mathrm{mol} \\
\mathrm{O}+\mathrm{hv}(\lambda \approx 91 \mathrm{~nm}) \rightarrow \mathrm{O}^{+}+\mathrm{e} & \Delta \mathrm{H}^{\circ}=1310 \mathrm{~kJ} / \mathrm{mol}
\end{array}
$$

Moving towards next layer - ozonesphere - sunlight meets molecules of ozone $\left(\mathrm{O}_{3}\right)$. In this way the next part of the radiation is absorbed by the ozone, which leads to $\mathrm{O}_{3}$ dissociation, resulting in the formation of excited molecules and atoms of oxygen (reaction 6):

$$
\mathrm{O}_{3}+\mathrm{hv}(\lambda<325 \mathrm{~nm}) \rightarrow \mathrm{O}_{2}^{*}+\mathrm{O}^{*}
$$

In addition, a small amount of solar radiation is absorbed during its passage through the troposphere.

As a result, after the absorption and dispersion in the atmosphere, the spectral range of solar radiation flux reaching the Earth's surface is slightly changed, mostly free of long-range radiation from ultraviolet as seen in Figure 3.

By assuming the all solar energy which reaches the earth's atmosphere amount 100 units, as many as 19 of them will be absorbed by molecules and suspensions occurring in the Earth's upper atmosphere. Other relative flows of solar radiation towards the Earth shows Figure 4. 


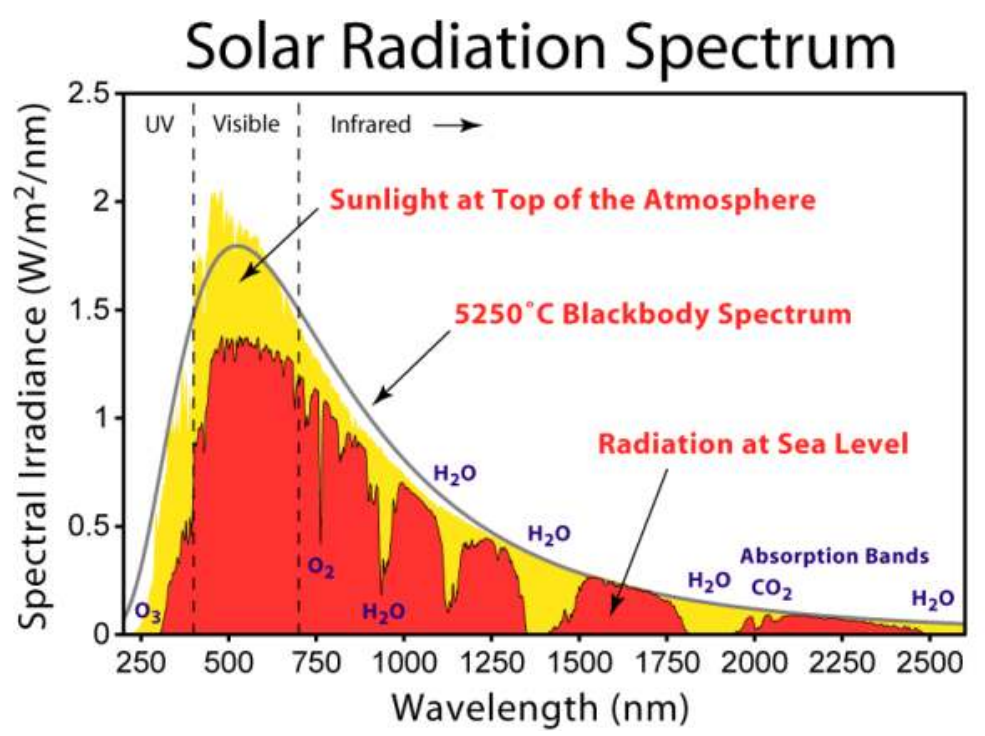

Figure 3. Sunlight spectrum before and after its passage through the atmosphere of the Earth [6]

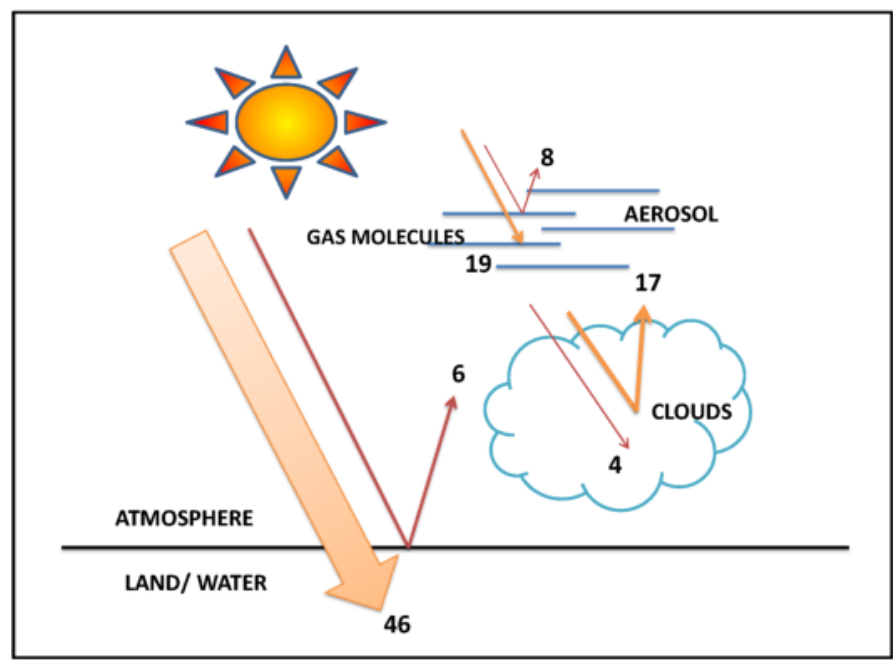

Figure 4. The flow of solar radiation reaching the Earth's surface [4 modified]

As shown in Figure 4, part of the solar radiation in general does not take part in the energy balance of the Earth - it is reflected to the space. 31 units is reflected including: 6 units directly reflected by the surface of the Earth, 8 units is reflected by aerosols, dust and other materials such as volcanic ash, and the remaining 17 units are reflected from the clouds. The value of 
solar radiation is expressed as a percentage by the number of Albedo. According to the calculations the Earth's Albedo amounts 31\%. From the remaining part of the solar energy (50 units) - 4 units are still absorbed by clouds of drops suspended in the water, in consequence remains 46 units. In this way only $46 \%$ of solar radiation reaches the Earth's surface and can be absorbed by the land and water. Radiation - a relatively high-and shortwave (UV and VIS) - is partially stored and used in different processes on the Earth, and part of it is reemitted into space in the form of long-wave radiation (infrared, IR) with less energy. Therefore, the total amount of energy absorbing solar radiation reaching the earth shield can be expressed by equation 7:

$$
\mathrm{E}_{\mathrm{s}}=\mathrm{F}_{\mathrm{s}}(1-\mathrm{A}) \pi \mathrm{r}^{2}
$$

where: $\mathbf{E}_{\mathrm{s}}$ - means the total amount of solar energy which is absorbed by the Earth (W)

$\mathbf{F}_{\mathrm{s}}$ - average flux of solar radiation (solar constant) $\left(1368 \mathrm{~W} / \mathrm{m}^{2}\right)$

A - (albedo) of the radiation reflected back into space (0.31)

$\mathbf{r}$ - the radius of the Earth $\left(6.3710^{6}\right)$

Therefore, the absorbed solar energy is approximately $1.210^{17} \mathrm{~W}$ (about $124600 \mathrm{TW}$ ) [7]. This amount of absorbed solar radiation is the driving force behind all the changes that are taking place on the globe. The solar energy transformation scheme, that reaches the Earth's surface is shown in Figure 5.

Most of the solar energy stream is directly converted into the heat, which is about $67 \%$ (nearly 83700 TW) of the radiation reaching the Earth's surface. About 32\% of this energy take part in the hydrological Earth cycle (about 40400 TW). The energy of water (oceans, seas, inland waters), tidal wave energy can be used to produce electricity in hydroelectric power plants such as the, so-called, flow power plants, which is based on a natural flow. Part of the solar energy is converted into kinetic energy of the wind. Around $400 \mathrm{TW}$ is used for air movement. Wind as an energy source was used in ancient times, and today the kinetic energy of winds is used to produce electricity by using wind turbines.

Other $100 \mathrm{TW}$ of solar radiation are driving forces behind the production of biomass. That organic matter is produced from the processing of solar energy through photosynthesis.

\section{The processes of photosynthesis and their impact on the biomass growth}

Green plants, some bacteria and protists have developed specific mechanism for synthesis of reduced carbon compounds, through which energy from the sun has been successfully transformed into a useful form of it. This process, which is one of the most important biochemical processes on the Earth, is called the photosynthesis. It's name comes from two ancient Greek words meaning "light" and "connect". Total formula for process of photosynthesis is a 


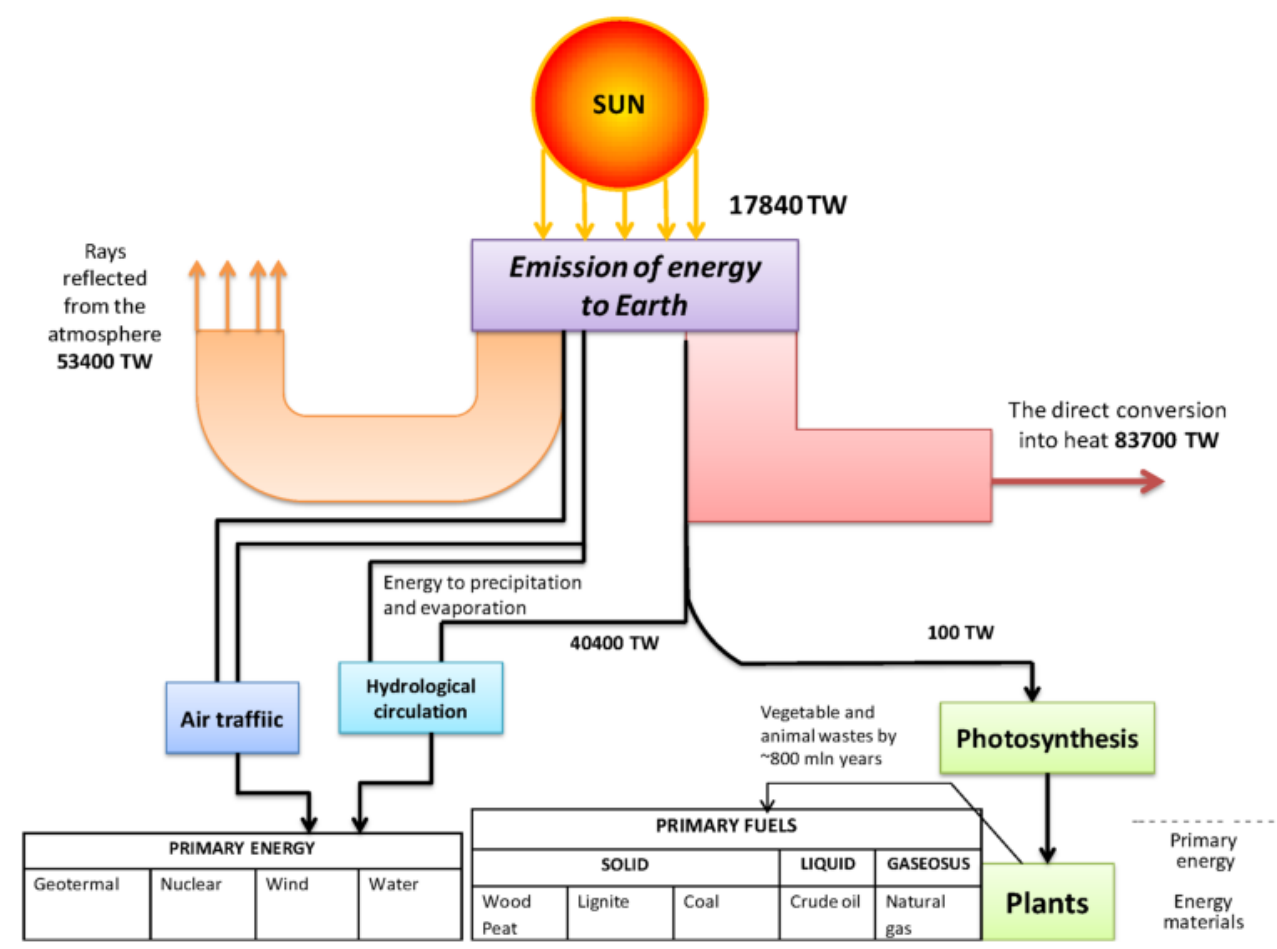

Figure 5. Diagram of solar energy transformations [7 changed]

reaction combining water molecules and carbon dioxide, in the presence of energy from the sun, to give the product as a basic sugar molecule, and oxygen as a byproduct (reaction 8).

$$
\mathrm{nH}_{2} \mathrm{O}+\mathrm{nCO}_{2} \rightarrow \mathrm{C}_{\mathrm{n}} \mathrm{H}_{2 \mathrm{n}} \mathrm{O}_{\mathrm{n}}+\mathrm{nO}_{2}
$$

If assumed the final product of photosynthesis is glucose, simple sugar molecule belongs to a group of a hexoses. Then the total reaction formula can be written as below (Reaction 9):

$$
6 \mathrm{H}_{2} \mathrm{O}+6 \mathrm{CO}_{2} \rightarrow \mathrm{C}_{6} \mathrm{H}_{12} \mathrm{O}_{6}+6 \mathrm{O}_{2}
$$

Photosynthesis can be distinguished by two sets of reactions: the light-dependent reaction and light-independent reaction (also called dark reactions of photosynthesis). The photosynthesis is initiate by solar radiation, falling on the surface of green plant leaves, is absorbed by assimilation pigments, acting as a catalyst [4]. There are two types of these pigments: chlorophyll $a$ and chlorophyll $b$. Chlorophyll molecules have strong absorption properties, absorbs solar energy from the electromagnetic spectrum in the range of $400 \mathrm{~nm}$ to $700 \mathrm{~nm}$. Radiation 
of this wavelength range is called Photosynthetically Active Radiation (PAR). The absorption spectrum of chlorophylls differing slightly from each other. Chlorophyll $a$ with total formula $\mathrm{C}_{55} \mathrm{H}_{72} \mathrm{O}_{5} \mathrm{~N}_{4} \mathrm{Mg}$ have blue-green color and absorbs light violet wavelength of $417 \mathrm{~nm}$, and the red one wavelength of $657 \mathrm{~nm}$. Chlorophyll $b\left(\mathrm{C}_{55} \mathrm{H}_{72} \mathrm{O}_{5} \mathrm{~N}_{4} \mathrm{Mg}\right)$ absorbs blue light in the field of $460 \mathrm{~nm}$ and red one $650 \mathrm{~nm}$ wavelength [8]. These small shifts of the both colors absorption maximums is the result of a small difference in the construction. The methyl group present in the chlorophyll $a$ has been replaced by an aldehyde group in the molecule of chlorophyll $b$ (Figure 6). The Range of the spectrum, useful for photosynthesis, is enhanced by auxiliary pigments - carotenoids, which have absorption properties of solar energy, not available for green chlorophyll. The color of the carotenoids is yellow-orange, which is the result of absorption by the blue-violet wavelength of $400 \mathrm{~nm}-495 \mathrm{~nm}$ (Figure 7) [9].

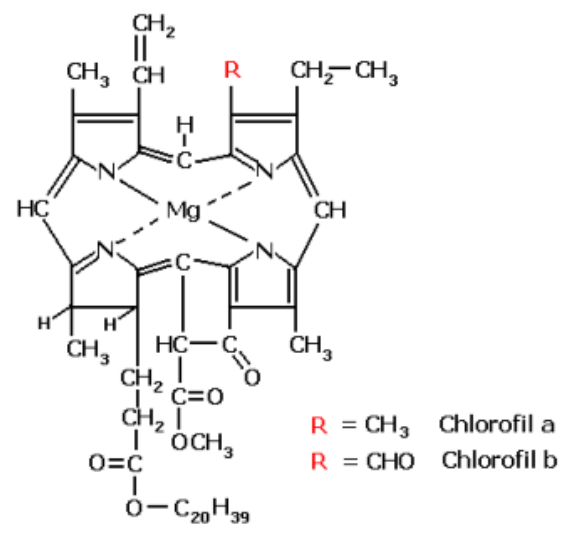

Figure 6. Differences between the structure of chlorophyll a and b [6]

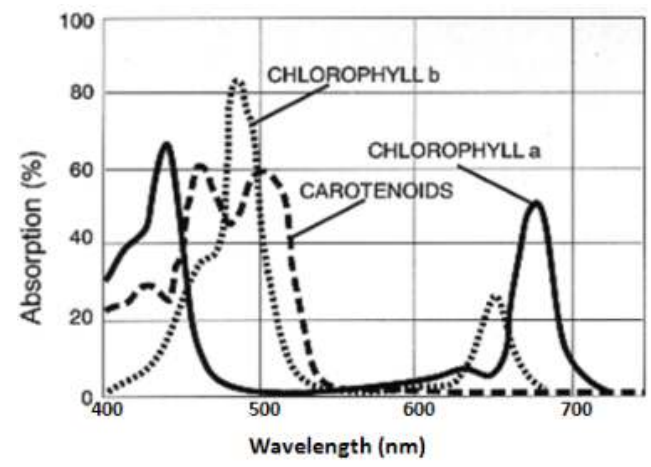

Figure 7. Absorption spectrum of carotenoids and chlorophylls a and b is a graph of light absorption by the different wavelengths of light [10] 
Chlorophylls and carotenoids can be found in chloroplasts tylakoids. Dyes are arranged briefly to form units called photosystem I and photosystem II. Visible light beam falling on the chlorophyll molecule, starts the electron excitation state of the magnesium ion at the center of the porphyrin ring. Excited electron is transferred into a conjugated bonds, and then transported to the neighboring molecule dyes. Thus, to pass the initial electron acceptor in photosystem II (which is ferrodoksin molecule) to photosystem I (where particles of quinone are primary acceptor) that ends on the molecule of coenzyme NADP + and reduce it to NADPH. Chlorophyll molecule, after return the electron, has strong oxidizing properties. Thus chlorophyll molecule by a specific protein complex containing manganese ions is able to receive the missing electron from the molecule of water. As a result this process the hydrogen protons and oxygen, the product called "side" photosynthesis is obtained. The result of electron beam movement are two compounds: ATP and NADPH. Produced so-called power of assimilation is necessary to carry out the dark reactions of photosynthesis. A further step of photosynthesis does not require solar energy. At this stage there is a series of reactions called the Calvin cycle where carbon dioxide is assimilated from the air. Subsequently, carbon dioxide is converted and in support of enzyme Rubisco is build in natural organic molecules [9].

Formation one molecule of glucose $\left(\mathrm{C}_{6} \mathrm{H}_{12} \mathrm{O}_{6}\right)$ required six Calvin rotation cycle and the energy in the form of 18 ATP molecules and 12 NADPH molecules.

A series of reactions, which constitute to the process of photosynthesis, are initiated by described light beam, falling into assimilation plants dye. Falling solar rays must have sufficient energy to cause an electron excited state in chlorophyll.

For full execution of photosynthesis, and specifically to reduce 1 mole of $\mathrm{CO}_{2}$ molecule is assumed that it takes 8 photons of red light having a wavelength $(\lambda=680 \mathrm{~nm})$, as shown in reaction 10 .

$$
2 \mathrm{H}_{2} \mathrm{O}+\mathrm{CO}_{2}+8 \mathrm{~h} v \rightarrow \mathrm{CH}_{2} \mathrm{O}+\mathrm{O}_{2}+\mathrm{H}_{2} \mathrm{O} ; \lambda=680 \mathrm{~nm}=1.81 \mathrm{eV} / \mathrm{h} v=174 \mathrm{~kJ} / \mathrm{mol} ; \Delta \mathrm{G}^{\circ}=479,1 \mathrm{~kJ} / \mathrm{mol}
$$

One photon of this wavelength has energy $=174 \mathrm{~kJ} / \mathrm{mol}$, therefore energy used in reaction is: 8 $x 174 \mathrm{~kJ} / \mathrm{mol}$. The free energy $\left(\Delta \mathrm{G}^{\circ}\right)$ of $\mathrm{CO}_{2}$ reduction reaction to $\mathrm{CH}_{2} \mathrm{O}$, amounts $479.1 \mathrm{~kJ} / \mathrm{mol}$, than photosynthesis efficiency $\eta_{\mathrm{f}}$ can be calculated:

Efficiency of photosynthesis $\left(\eta_{\mathrm{f}}\right)=$ Energy used/Energy Supplied;

substituting: $\eta_{\mathrm{f}}=479,1 \mathrm{~kJ} \mathrm{~mol}^{-1} / 8174,0 \mathrm{~kJ} \mathrm{~mol}^{-1}=0,34 \mathrm{~kJ} \mathrm{~mol}^{-1}$

Thus, the ratio between the used energy to the energy put into the photosynthesis process amounts approximately $34 \%$. However, in real conditions only this part of the radiation that can be absorbed by the Earth's surface should be considered. However only about $0.1 \%$ of this energy takes part in photosynthesis. In more precise calculations and considering such losses such as "photobreathing" of plants or microbiological decomposition, in practice the efficiency of photosynthesis does not exceed 5\% [11].

Each year around the globe are synthesized billions tones of organic compounds that serve as nutrients not only for producers, but also for living organisms, which are on higher levels of 
ecological pyramid. Biomass as an organic matter is simply result of change-over driven by solar energy.

\section{Biomass as an energy source}

Solar energy, as a result of guided for over 3.5 bn years of photosynthesis, is accumulated in the form of organic matter called biomass. In this way, solar radiation is converted into a solid form, which can be used further, not only by organisms in the food chain, but also can provide a raw material for the production of effective energy.

The definition of biomass according with Directive 2009/28/WE is: „biodegradable fraction of products, waste and residues from biological origin from agriculture (including vegetal and animal substances), forestry and related industries including fisheries and aquaculture, as well as the biodegradable fraction of industrial and municipal waste" [12].

However, this definition does not fully covers the meaning of biomass, because its forms are not just a production side effect of other converting processes. There are also dedicated plantation for energetic purposes only. In other words are established the specific energy crops cultivation.

Biomass energy resources are divided into three main groups: [13,14]:

- agricultural biomass (energy crops),

- forest biomass (firewood, waste from wood industry and paper industry),

- and all organic waste from agriculture, forestry as well as gardening.

- The basic division of biomass and their byproducts are distinguished as follows due to its physical state:

- solid biomass (that is wood, straw, energy crops, briquette, pellets),

- liquid (liquid and gaseous) energy carriers from biomass processing,

- Depending on the degree of physical, chemical or biochemical processing of biomass, it can create:

- primary energy sources - wood, straw, energy crops,

- secondary energy sources - slurry, manure, sewage sludge and other organic waste,

- processed energy sources - energy carriers, that is biofuels (bioliquids) [14,15]

The potential of biomass in the world according to the German Electricity Industry Association (VDEW- German Verband der Elektrizitaetswirtschaft) is about 150 bn Mg per year, which equal to $120 \mathrm{bn} \mathrm{Mg}$ of coal. Resources of this biomass exceeds over ten times the current world demand for energy. However, from this potential biomass amount, only about $20-30 \%$ is suitable to be used, and in fact only $6 \mathrm{bn} \mathrm{Mg}$ of plant biomass is suitable for use [16]. Biomass 
resources in Poland are estimated at $30 \mathrm{mln} \mathrm{Mg}$ per year, which is the energy equivalent to $16-19 \mathrm{mln} \mathrm{Mg}$ of coal/ year and is about (110... 130) TW [16] (an average of about 11\% of total consumption). For example, to supply biomass to power plant with a capacity of $1 \mathrm{MW}$ ( = $0.000001 \mathrm{TW}$ ) about $5000 \mathrm{Mg}$ of dry weight of the raw material is needed. This amount is equivalent to the coverage of the field area less than 500 ha, and assuming $10 \%$ of the density the crops, which is to cover an area of approximately $50 \mathrm{~km}^{2}$ [17]. The sample calculations show, that required energy consumption for biofuels from biomass in the EU's cover area about $79000 \mathrm{~km}^{2}$, which can be compared with the area of the Czech Republic [18].

According to the above figures, the existing biomass resources, and thus the energy efficiency of this raw material is not enough to cover the world's growing demand for energy. It is mean the agricultural land used for food crops should be replaced to a large extent by energy crops plantations, and this way increase the food prices.

Biomass as a solid biofuel is a raw material after suitable processing is used for heat and electricity generation. Conversion of solid biomass for energy purposes can occur by two main pathways (Table 1 and 2) [14, 7]:

1. First one include processes of direct combustion of solid biomass such as in boilers and power plants or by biomass gasification and then combustion of the resulting gas (syngas).

2. The alternative path of energy accumulated in the biomass is to process biomass to liquid biofuels, which are liquid energy carriers for transport.

\begin{tabular}{|c|c|c|}
\hline Process & Combustion & Gasification \\
\hline Conditions & $\begin{array}{l}\text { - The excess oxygen in the co } \\
\text { chamber } \\
\text { - Temperature: } 800-1450^{\circ} \mathrm{C}\end{array}$ & $\begin{array}{l}\text { Phase I: drying and degassing of the } \\
\text { material the shortage of oxygen, } \\
\text { temperature: } 450-800^{\circ} \mathrm{C} \text { Phase II: } \\
\text { combustion gases in the presence of } \\
\text { excess oxygen, at: } 1000-1200^{\circ} \mathrm{C} \text { Phase } \\
\text { III: heat transfer in the heat exchanger }\end{array}$ \\
\hline Final products & $\mathrm{CO}_{2}, \mathrm{H}_{2} \mathrm{O}$ & $\begin{array}{l}\text { Mixture of gases: } \mathrm{CO}_{2}, \mathrm{~N}_{2}, \mathrm{H}_{2}, \mathrm{CO}, \mathrm{C}_{x} \mathrm{H}_{\mathrm{y}} \\
\mathrm{CH}_{4} \text { and others. }\end{array}$ \\
\hline Energy & Heat energy/ electricity & Heat energy/ electricity \\
\hline Effectivity & $\sim 15-20 \%$ & $\sim 35 \%$ \\
\hline
\end{tabular}

Table 1. Technologies of the direct use of solid biomass (pathway 1)

Combustion of solid biofuels is the most common and easiest, but inefficient method of getting energy. Because the biomass is a mixture of organic compounds such as carbohydrates, the combustion reaction can be presented in simpler form of equation (11):

$$
\left[\mathrm{CH}_{2} \mathrm{O}\right]+\mathrm{O}_{2} \rightarrow \mathrm{CO}_{2}+\mathrm{H}_{2} \mathrm{O} \quad \Delta \mathrm{H}=-440 \mathrm{~kJ}
$$


Above equation is a simple reverse of the photosynthesis reaction. It can be assumed that this form of solar energy conversion, accumulated in the form of a green plant organic matter is completely depends on carbon dioxide emitted to the atmosphere. As it has been calculated, during the combustion of fossil carbon for every $1 \mathrm{GJ}$ of energy is produced $112 \mathrm{~kg}$ of carbon dioxide emissions. In this calculation for biomass (assuming the simplified formula $-\mathrm{CH}_{2} \mathrm{O}$ ) the amount of $\mathrm{CO}_{2}$ emitted per each $1 \mathrm{GJ}$ of energy is around $100 \mathrm{~kg}$, which is slightly advantage over the coal. However, it is suggested, the final energy balance of biomass combustion process is zero, because of $\mathrm{CO}_{2}$ emitted during combustion process is equal to the amount of gas which is absorbed by the organism during the plant growing season [4]. However, the rate of biomass growing in time is not enough, to compensate the $\mathrm{CO}_{2}$ emitted into the atmosphere. The plants during the growing season, green organisms need about 10 years [4] in ideal conditions for example with proper lighting, temperature and humidity. In order to support the performance of biomass energy crops increase are also used different mixes, fertilizers and pesticides, which are produced from natural gas. It is estimated, to get a $25 \%$ share of biomass fuels will lead to increase use of NPK fertilizers by $40 \%$ [4, 19]. Plant protection products and supporting substances causes additional emissions of greenhouse gases into the atmosphere such as $\mathrm{N}_{2} \mathrm{O}$. Because of combustion of the solid biomass is not only $\mathrm{CO}_{2}$ or $\mathrm{N}_{2} \mathrm{O}$ emission, but also carbon oxide (CO), sulfur compounds, or other combustion residues such as fly ash and dust.

\begin{tabular}{|c|c|c|c|c|c|c|c|c|c|}
\hline \multicolumn{10}{|c|}{ BIOMASS } \\
\hline \multicolumn{3}{|c|}{$\begin{array}{l}\text { Edible parts of plants } \\
\text { (seeds, grains, fruits) }\end{array}$} & \multirow{2}{*}{\multicolumn{7}{|c|}{$\begin{array}{c}\text { Non-edible parts of plants which are agricultural waste or derived from } \\
\text { energy crops }\end{array}$}} \\
\hline \multicolumn{2}{|c|}{$\begin{array}{l}\text { Containing } \\
\text { starch }\end{array}$} & $\begin{array}{l}\text { Containing } \\
\text { vegetable oils: } \\
\text { rapeseed, palm } \\
\text { oil, sunflower oil }\end{array}$ & & & & & & & \\
\hline \multirow{2}{*}{\multicolumn{2}{|c|}{ Fermentation }} & \multirow[b]{2}{*}{ Transesterification } & \multicolumn{2}{|c|}{ Fermentation processes } & \multirow{2}{*}{\multicolumn{3}{|c|}{ Gasification }} & \multirow{2}{*}{\multicolumn{2}{|c|}{ Thermolysis }} \\
\hline & & & $\begin{array}{c}\text { Fermentation: } \\
\text { anaerobic } \\
\text { ethanol butanol }\end{array}$ & Fermentation & & & & & \\
\hline Ethanol & Butanol & Biodiesel & Methane & $\begin{array}{c}\text { Short fatty } \\
\text { acids }\end{array}$ & \multicolumn{3}{|c|}{ Syngas } & $\begin{array}{l}\text { Light } \\
\text { gases }\end{array}$ & $\begin{array}{l}\text { Oil } \\
\text { fractions }\end{array}$ \\
\hline & & & & & \multicolumn{3}{|c|}{ Fischer-Tropsch Synthesis } & & \\
\hline & & & & & DME & Methanol & Diesel & & \\
\hline
\end{tabular}

Table 2. Examples of processes to convert biomass to liquid biofuels [21]

The efficient combustion of such material needs advanced techniques for boilers, allowing the complete combustion of volatile products of biomass pyrolysis. The incomplete combustion of biomass significantly reduces the efficiency of the process. In addition, low-density of biomass causes difficulties in its storage and transport, which creates extra costs. A large range 
of moisture content, within the ranges $50 \ldots 60 \%$ gives the energy value $(6 \ldots 9) \mathrm{MJ} / \mathrm{kg}$. On the other side biomass dried has calorific value up to $19 \mathrm{MJ} / \mathrm{kg}$ [20]) which is also difficult and costly for preparation to use in the heat and electricity production. Consequently, because of the above reasons, considering the whole process, namely from the operation of farm machinery, through the transport, processing of biomass (drying, degassing of material, seal or change of boilers). Finally the combustion of biomass is not efficient to cover the still increasing demand for energy. A good solution of the shortage problem of biomass used for energy purposes could be manufacturing biomass by microorganisms such as algae, which will be discussed later in this chapter.

Mentioned alternative process for the recovery of solar energy collected in photosynthetic organisms is subjected to physical, chemical or biochemical conversion of biomass (pyrolysis, gasification, fermentation, distillation) [4]. In this way the converted form of biomass is called liquid biofuels, which sample preparation processes are shown in Table 2.

\section{Biofuels}

In 1900 at the World Exhibition in Paris, Rudolf Diesel introduced the high-pressure engine driven with clean oil from arachidic peanuts. Twenty years later Henry Ford introduced the possibility to power the internal combustion engines with spark ignition by ethanol. Mixtures of alcohol and gasoline as a fuel $(30: 70 \mathrm{v} / \mathrm{v})$ was reported for using in 1929 in Poland. One of the first scientific publications regarding the possibility of using these compounds to power the engines of tractors has been published in Polish journal "Chemical Industry" [22].

In the expected terms of production and use of biofuels (alternative fuels), it is assumed that those fuels should:

- to be available in sufficiently large quantities;

- demonstrate a technical and energetic properties of determining their suitability to supply the engines or heating devices;

- to be cheap in production and has attractive price for costumers;

- has a low risk for environment than the fossil fuels, by less emission of toxic compounds and greenhouse gases in the combustion process;

- provide an acceptable economic indicators of engines or boilers and safety of their use, and enable the lower operating costs of the equipment;

- increase the energy independence.

Until now, there are several complementary definition of biomass. Previously cited European definition mentioned in the European Directive 2009/28/EC and the biomass as the main source of raw materials for the biofuels production. The European definition distinguish two basic raw material pathways and corresponding them technologies, namely BtL processes ("biomass 
to liquid"), alternatively BtG ("biomass to gas") and WtL ("waste to liquid"), alternatively WtG ("waste to gas").

The Directive also introduced bioliquids as liquid biofuels for other than transport purposes, like production of electricity, heat and cooling. The introduction of "xtL processes" identifies general processes for conversion of biomass instead of distinguishing of second, third and fourth generation biofuels. Apart from this there was defined the term "synthetic biofuels" describing them as synthetic hydrocarbons or their mixtures gained from biomass, such as SynGas produced in the gasification process of forest biomass or SynDiesel.

This division resulted from the conditions described above, and first from the assess the suitability of fuels in modern engine technology and availability of raw materials and their impact on the environment. The formal division of biofuels on the appropriate generations has been published in the report "Biofuels in the European Vision, the Vision 2030 and Beyond". This report divided biofuels into the first generation biofuels, so-called "conventional biofuels" and the second generation biofuels, so-called "future biofuels".

The first generation biofuels (,,conventional biofuels”) includes:

- bioethanol (BioEtOH, BioEt), understood as a conventional ethanol gained from hydrolysis and fermentation processes from raw materials such as grain, sugar beets and so on.

- pure vegetable oils (PVO-pure vegetable oils), got from cold pressing processes and the extraction of oilseeds;

- biodiesel, which is rapeseed oil methyl ester (RME) or methyl and ethyl esters (FAME and FAEE) of higher fatty acids or from the other oleaginous plants, obtained by the process of cold pressing, extraction and transesterification;

- biodiesel, which is the methyl and ethyl esters gained by transesterification of waste oils;

- biogas got by purification processes of damp waste or agriculture raw biogas;

- bio-ETBE, got from the chemical transformation of bioethanol.

- To the biofuels of the second category ("future biofuels") have been classified as follows:

- bioethanol, biobutanol and mixtures of higher alcohols and their derivatives got by the advanced hydrolysis and fermentation process of lignocellulose biomass (except of raw materials for food purposes);

- synthetic biofuels, which are products of biomass change-over by gasification and follow by catalytic synthesis for hydrocarbon fuel components in BtL processes.

- fuel for diesel engines gained from lignocellulosic biomass processing through the FischerTropsch processes;

- biomethanol obtained by the processes of lignocellulose transformation, including the Fischer-Tropsch synthesis and also with use of waste carbon dioxide; 
- biodimethylether (bioDME) obtained in thermochemical biomass conversion processes, including methanol, biogas and synthesis gases which are derivatives of biomass conversion processes;

- biodiesel as a biofuel or as a biocomponent for diesel engines derived by hydrogen refining (hydrogenation) of vegetable oils and animal fats;

- biodimethylfuran (bioDMF) derived from the processing of sugars, including cellulose, in biochemical and thermochemical processes;

- biogas as a synthetically derived natural gas - biomethane (SNG), obtained through the lignocellulose gasification processes and the appropriate synthesis and by purification processes of biogas from agriculture, landfills and sewage sludge;

- biohydrogen obtained by gasification of lignocellulose and synthesis of gasification products or through the biochemical processes.

The concept of the second generation biofuels is based on the assumption, the raw material for its production should be biomass as well as waste vegetable oils and animal fats, and any residual organic materials, unsuitable for the food industry or forestry.

Department of Transport and Energy of the European Commission proposed to separate the third generation biofuels, as those for which the technological development and their implementation into operation can be estimated for the years 2030 and beyond. To those fuels the biohydrogen and biomethanol were included as well.

The fourth generation biofuels has different definitions but one of the simplest says about crops that are genetically engineered to consume more $\mathrm{CO}_{2}$ from the atmosphere than they'll produce during combustion later as a fuel. Both of these biofuels groups are included in the future biofuels group ("advanced biofuels"). Thus, the third generation biofuels can be got through the similar method as the second generation biofuels, but from the modified (at the cultivation stage) raw material (biomass) by means of molecular biological techniques. The purpose of these modifications is to improve the process of converting biomass to biofuels (biohydrogen, biomethanol, biobutanol), for example by growing trees with low lignin content, development of crops with respectively built enzymes, etc.

The proposal of split the new, fourth generation of biofuels was established due to the need to close the balance of carbon dioxide or eliminate its impact on the environment. Road Map 2050 prepared by the European Commission talks about CCS (Carbon Capture and Storage) [23], but repeatedly claimed that it is a commercial unimplemented technology. Many companies and organizations have social and environmental objections to implement it. Something that is more reasonable and what should be lean is CCU (Carbon Capture and Utilization). It would be profitable to capture $\mathrm{CO}_{2}$ from the atmosphere or the exhaust of power stations and convert it to fuel by using a sustainable source of energy such as sunlight. Photocatalytic or termochemical conversion of $\mathrm{CO}_{2}$ to fuels by using semiconductors and metal oxides are two main routes. There is also combination of these routes by using water or hydrogen co-fed with $\mathrm{CO}_{2}$ for fuels generation. 
There are developed new, forward-looking technologies in the U.S. and Europe characterized by high reduction of $\mathrm{CO}_{2}$ by means of LCA (Life Cycle Assessment) parameter of specific biofuel like:

- biofuel production technologies, including Jet type, by culturing algae without sunlight from agricultural sludge, grass and waste substances, with the use of carbon dioxide (technology "SOLAZYME");

- technology of plasma gasification of waste biomass and municipal and industrial waste (BtG and $\mathrm{WtG}$ processes), followed by processing upgraded synthetic gas towards liquid biofuels like GTL diesel and Jet type fuel ("SOLENA" technology, carried out in the UK and Italy);

- technology of carbon dioxide use in the carrier energy production processes;

- complex biorefinery technologies.

European strategy mentioned in the "European Strategic Research Agenda, Update 2010" defines the following biofuels as a prospective and showing the technological pathways of its getting:

- synthetic fuels/hydrocarbons from biomass gasification (application: transport fuels from RES for jet and diesel engines);

- biomethane and other gas fuels from biomass gasification (substitutes of natural gas and other gas fuels), (application: engine fuels and high efficient energy production);

- biofuels (bioliquids) from biomass got through the other thermochemical processes such as pyrolysis (application: heating fuels, electricity production or indirectly through the xTL processes for transport fuels);

- ethanol and higher alcohols from sugars containing biomass (application: transport fuels from RES or as a petrol biocomponents, E85);

- hydrocarbons from biomass, got from sugars, created in biological or chemical processes (application: renewable transport fuels for jet and diesel engines);

- biofuels gained from the use of carbon dioxide for the microorganisms production or from the direct synthesis of carbon dioxide in thermal and biochemical processes (applications: transport fuels and for aviation).

International Energy Agency, have been identified also "solarfuels" ("solar fuel").

It is necessary to determine the best and universal technologies of their production. The technologies of biofuels production have to provide the possibility of safe operation of engines while reducing exhaust emissions of toxic ingredients under the needs of the relevant class "EURO" in Europe and the U.S./ California ULEV in the USA. At the same time it is important that biofuels with a similar composition and properties should be available in every country, because of the motor requirements.

That's why the developed by the International Energy Agency, road map for biofuels in transport ("Technology Road map. Biofuels for Transport") determines the perspective biofuel technologies in the world till 2050. Therefore it was proposed to divide the conventional 
("conventional") and future ("advanced") biofuels. Distribution and severity of various biofuels in both groups, according to the MAE, is shown in Figure 8.

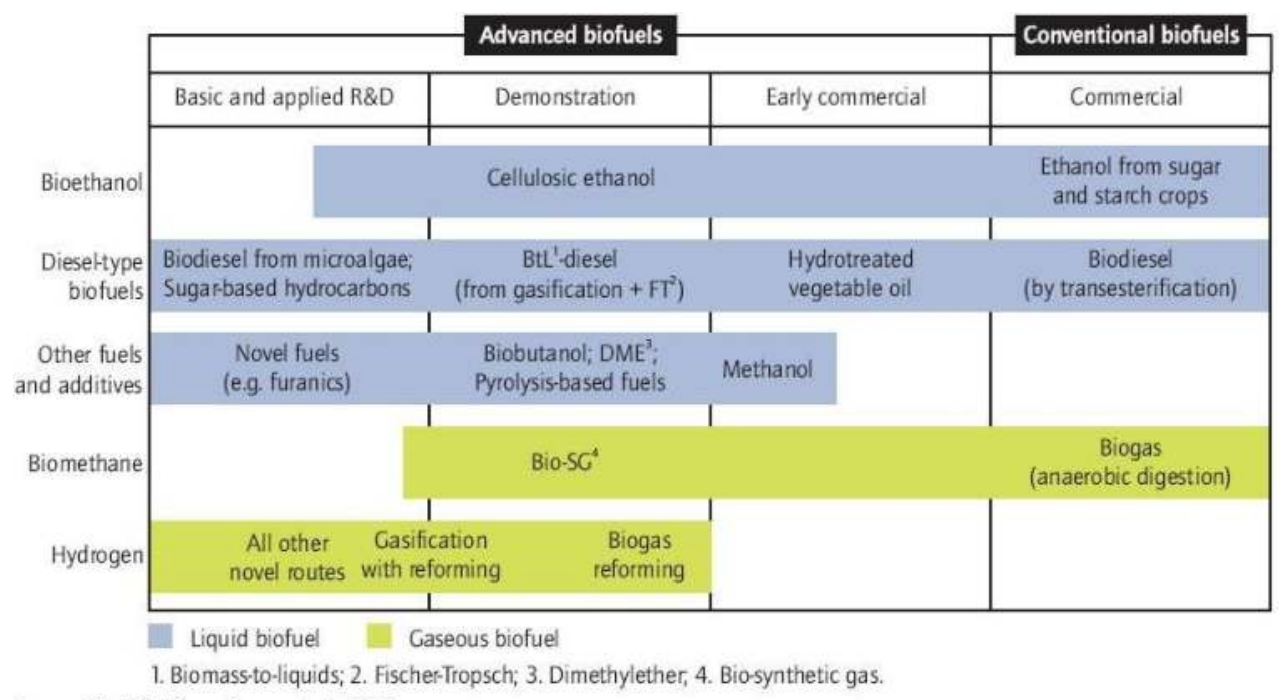

Source: Modified from Bauen et al., 2009.

Figure 8. Biofuels division and stage of its production (Technology Roadmap Biofuels for Transport $\odot$ OECD/IEA, 2011) [24] with the consent of: OECD/IEA.

The target biofuels production in 2050 required a biomass material with a total energy potential estimated at $65 \mathrm{EJ}$, which is equivalent to $100 \mathrm{mln}$ ha of cultivations in 2050. Assuming that $50 \%$ of the feedstock for the advanced biofuels production will come from waste substances (XtL processes). This means that it is necessary to increase the area devoted for cultivation of biomass for energy purposes. In an optimistic scenario, it is assumed the possibility to get 145 EJ per year of energy from biomass and all kinds of waste substances intended for liquid energy carriers for transport and for heat and electricity in the polygeneration. Estimated reducing of $\mathrm{CO}_{2}$ emissions is determined at 2.1 Pg per year, with the share of biofuels of $27 \%(\mathrm{v} / \mathrm{v})$ of the total amount of transport fuels.

Considering the demand for biofuels that meet the future needs for transport, including air transport, and their ability for $\mathrm{CO}_{2}$ reduction, it was established by MAE the following biofuels and their technology paths:

- fuels from BtL processes (synthetic hydrocarbons compositions), get by fast pyrolysis, by heating biomass at temperature between $(400 \ldots 600)^{\circ} \mathrm{C}$, and then applied fast cooling. The volatile compounds may be converted to a bioliquid or further catalytic deoxygenation, distillation and refining toward fuel component. The solid residue is called "Bio-char" 
("charcoal") and as a by-product can be used as a solid fuel, or used as a sequestration agent and for soil fertility;

- diesel oil from BtL processes, so-called FT-diesel obtained by conversion to the synthesis gas and catalytic Fischer-Tropsch synthesis (FT) in a wide range of liquid hydrocarbons, including synthetic diesel and JET type biofuels;

- hydrorafinated vegetable oil (HVO) as a fuel for diesel engines or heating oil produced by the hydrogenation of vegetable oils or animal fats (non-food and waste). The first commercial plants started in Finland and Singapore;

- cellulosic bioethanol from lignocellulosic raw materials produced by the biochemical conversion of cellulose and hemicelluloses followed by fermentation of sugars (IEA, 2008a);

- biogas obtained by anaerobic digestion of raw materials, such as organic waste, animal manure and sewage sludge, than purified to the biomethane form (SNG!!) by removing $\mathrm{CO}_{2}$ and hydrogen sulfide $\left(\mathrm{H}_{2} \mathrm{~S}\right)$. Can be applied in transport as methane fuels (bioCNG, bioLNG) or as a source of hydrogen, also for the fuel cell;

- dimethyl ether (bioDME) as gas fuel for diesel engines, derived from methanol catalytic dehydration process, from synthesis gas by gasification of lignocellulose and other biomass. BioDME production from biomass gasification is at the demo phase (September 2010 in Sweden (Chemrec));

- biobutanol have a higher energy density than ethanol in petrol. It can be shared through the existing network for gasoline, Biobutanol can be produced by sugars fermentation using bacteria, Clostridium acetobutylicum. Demonstration plants are working in Germany and in the USA, the others are under construction.

- furan fuels in the latest "Technology road map, biofuels for transport", compiled by the International Energy Agency, were classified as prospective biofuels. Compounds such as furfural and 5-hydroxymethylfurfural (HMF) can be obtained with good yield through dehydration of monosaccharides, such as hexoses (e.g. fructose) or pentoses (e.g. xylose) in the presence of various catalysts. Fuel is suitable for spark-ignition engines with the advantages when compering with ethanol.

- solarfuels, obtained by gasification of biomass towards synthesis gas by using heat produced by concentrating solar energy. They can also be obtained by decompose of water (water vapor) and the use of carbon dioxide to form synthesis gas catalytically transformed into fuel fractions. In terms of the production of these fuels can be included technology of so-called "Artificial leaf";

- biorefinery for liquid fuels production and chemical by-products, which discussion exceeds the scope of this chapter.

In terms of the most promising biomass for the future biofuels production, considering socalled "land hunger" ("ground competition") and the needs in terms of $\mathrm{CO}_{2}$ emissions, can be distinguished following cultivation: algae, camelina, jatropha, and halophytes. Under development are new technologies without sunlight ("dark"), marine photosynthetic membrane systems for the algae production, as well the technologies for biomethanol production. 


\section{Technologies of liquid energy carriers production based on waste substances}

\subsection{WtL (Waste to Liquid) and WtE (Waste to Energy) processes}

Dynamically observed population increasing in the world stimulates fast economic growth. This is related with growing demand for all kinds of products and energy. In result of progressive consumption, waste generation is increasing. According to the data total amount of waste, which is generated in the European Union, maintains an upward trend. Municipal solid waste (MSW) amounted 150 million Mg in 1980. In 2005, increased up to 250 million Mg, and forecasts for 2015 growth is estimated up to 300 million $\mathrm{Mg}$ [25]. The constantly increasing amount of waste contributed in overfilled existed landfills, forces society for development of new landfills. The overfilled landfills are big the social and environmental problem. Therefore, novel energy technologies have preferences for waste treatment WTE (Waste to Energy), or for receiving new products from waste in the process of WTP (Waste to Product.). Waste treatment processes for liquid energy carriers are processes WTL (Waste to Liquid). The trends for conventional energetic waste utilization are based on direct combustion and more advanced thermochemical methods such as pyrolysis, gasification, and plasma technologies under development since 1970. Figure 9 shows the main alternative methods of converting waste to energy in WTL and WTE processes [25].

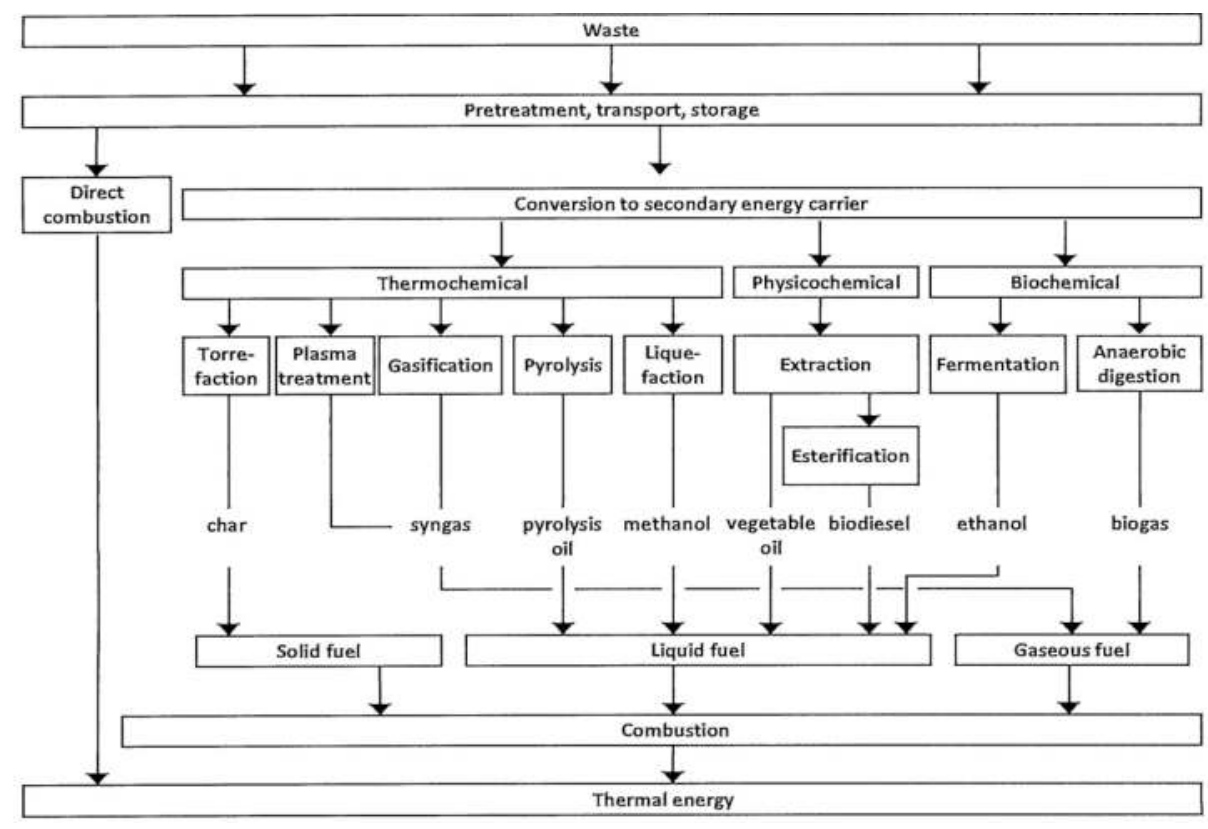

Figure 9. Waste to Liquid and Waste to Energy conversion technologies [25], with the consent of: Anouk Bosmans 
In the WTL and WTE processes, pre-treated waste is converted into secondary energy carriers using thermochemical methods: physico-chemical or biochemical. As a result of these changes is obtained biofuels solid, liquid or gas. These fuels are burned and converted into thermal energy. WTL processes path is shown in Fig.9..

A HTU is processing waste into liquid biocrude oil (Hydro-Thermal Upgrading), at high temperature and pressure near supercritical condition of water, which is usually the solvent in this process, the basic conditions are shown in Table 3.

\begin{tabular}{ll}
\hline Conditions & Temperature: $(300 \ldots 350)^{\circ} \mathrm{C}$ \\
& Pressure: $(120 \ldots 180)$ bar \\
& Reaction time : $(5 \ldots 20)$ minutes. \\
\hline Feedstock & All types of biomass, domestic, agricultural and industrial residues, wood. \\
& Also wet feedstocks, no drying required. \\
\hline Chemistry & Oxygen removed as Carbon Dioxide \\
\hline Products & 45 Biocrude $(\%$ w on feedstock, dry basis) \\
& 25 Gas ("/>90\% $\left.\mathrm{CO}_{2}\right)$ \\
& $20 \mathrm{H}_{2} \mathrm{O}$ \\
& 10 dissolved organics (e.g., acetic acid, methanol) \\
\hline Thermal efficiency & $70-90 \%$ \\
\hline
\end{tabular}

Table 3. Basic physical and chemical conditions of the process HTU [26]

HTU process developed by Shell in $80^{\prime}$ s occurs at a temperature up to $350^{\circ} \mathrm{C}$ and a pressure about 180 bars. HTU can be used to convert liquid fuel from a wide range of biomass feedstock, without the need of drying raw material. It has been designed to carry out the reaction in the excess of water, under supercritical condition of water. The final product is a "bio-oil" ("biocrude") with properties similar to crude oil, so it can be used after upgrading as fuel in boilers, turbines and so on. The calorific value (LHV) of biocrude obtained this way amount $30 \ldots 35$ $\mathrm{MJ} / \mathrm{kg}$ [27].

Another an example of a technology for waste conversion is based on the catalytic thermal depolymerization patented by Alphakat $\mathrm{GmbH}$, which principle of operation is shown in Figure 10.

KDV process takes place in a special industrial installation known as KDV Unit. As can be see from Figure 10, the whole system is a closed with strictly defined conditions: the process is carried out at $\sim 350^{\circ} \mathrm{C}$, under low vacuum 0.9 bar. The vacuum is maintained in the system by special vacuum pumps. As shown in the figure, the pump mix the raw material provided with a catalyst causing the circulation of the reaction mixture in a closed system. After heating the batch by thermal oil up to $\sim 350{ }^{\circ} \mathrm{C}$, volatile organic compounds (VOC) are formed, which at the main distillation column undergo separation for diesel and gasoline fraction [29, 30].

Using KDV technology a wide range of raw materials derived from biomass or waste materials, either organic or mineral, can be process. Table 3 summarizes the basic substances that can be 
used as a feedstock in KDV plant. We can see all kinds of biomass waste, agricultural, municipal and industrial sewage, as well as synthetic materials.

\section{RAW MATERIAL}

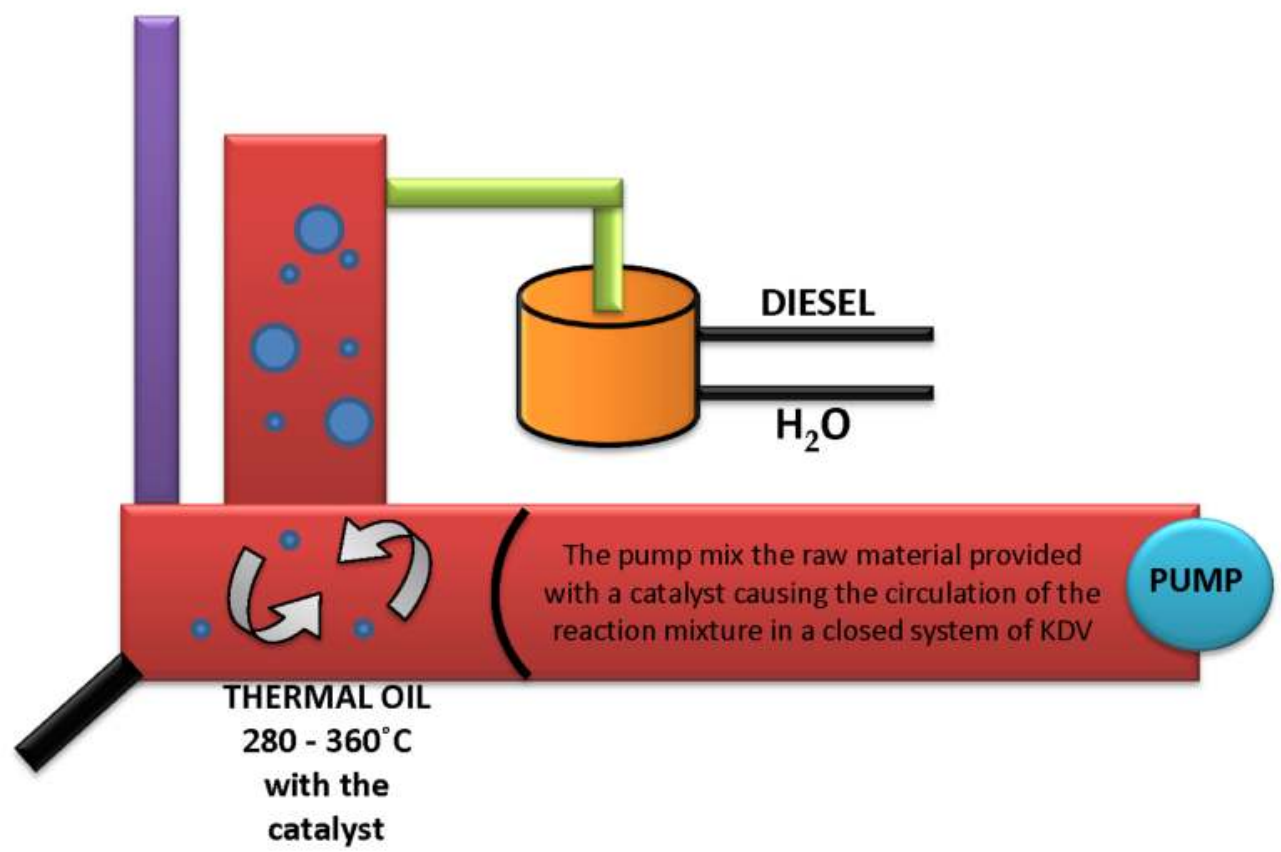

Figure 10. The principle operation of KDV technology [28 modified]

\begin{tabular}{|c|c|c|}
\hline Lp. & Type of material & Sort of material \\
\hline 1 & Biomass (C-3 and C-4 plants) & $\begin{array}{l}\text { - grown energy sources like Jatropha, } \\
\text { - wood, biogenous residues like leaves, straw, etc. }\end{array}$ \\
\hline 2 & Waste & $\begin{array}{l}\text { - Industrial Waste (IW), } \\
\text { - Municipal Solid Waste (MSW), } \\
\text { - agricultural waste, } \\
\text { - waste oil (also contaminated oil), } \\
\text { - refinery residues, bitumen. etc, } \\
\text { - dried sludge from sewage treatment plants, } \\
\text { - rubber and tires. }\end{array}$ \\
\hline 3 & Synthetic materials & - All kinds of plastics and synthetic materials (PVC, PP, PET, etc.) \\
\hline
\end{tabular}

Table 4. Basic substances which can be used as raw material for the KDV installation [29, 30] 
The main products from KDV plant is synthetic diesel fuel or kerosene depends on process parameters [30]. However these fuels are available after catalytic hydrotreatment process (like hydrodesulphorization in refinery), because the product after distillation has still properties of biocrude oil. KDV were started as a demo units in Germany, Canada, Spain and Mexico and recently in Poland [31].

\subsection{Overview of selected technologies for liquid biofuels from waste carbon dioxide}

\subsubsection{Conversion processes}

Scientists all over the world are trying to learn the essence of the photosynthesis process. Already in 1912, the Italian chemist Luigi Giacomo Ciamician in the Science magazine, said the society should be transfered from a civilization based on oil and coal and start using clean energy from the sun. He thought that by using appropriate photochemical reactions and using the new compounds is possible to discover the mystery of the photosynthesis guarded plants.

In July 2010, in the United States was established Joint Center for Artificial Photosynthesis JCAP, funded by the U.S. Department of Energy (DOE). The aim of this project is to develop a method able to copy the photosynthesis process, available to establish the path for the production of liquid fuels using waste carbon dioxide.

According to information provided by JCAP [32], major challenges facing scientists dealing with the artificial photosynthesis is a system that consists of key elements of the process: the visible light absorber, catalyst and membrane switches.Visible light absorber is a molecule that is designed to capture and convert the sunlight with the high efficiency, like the chlorophyll in plants. Absorbed energy puts absorber molecules into excited state, in which all the light energy is submitted to electron. Properly designed absorber pushes the electron from the shell, directing him to an adjacent molecule (in the same way as it does in natural photosynthesis, where electrons jump from photosystem I to photosystem II). In this way formed electron beam passes through a further conveyor releasing the energy required for further electrochemical reaction. At the point of detachment of the electron take place creation so-called. "Hole," or positive charge. At this point is necessary a catalyst that efficiently breaks the water molecule, this way is freed the missing electron in place of created "hole". In natural photosynthesis complex of the protein, which contains manganese ions act as the catalyst. This compound is still a great mystery because it is not yet possible to copy of its complex structure in the laboratory. Therefore, research is continuing to find a suitable replacement, which will perform a similar sequance cleavage involving water molecules processed by the solar energy absorber. Catalyst must not only be efficient and sustainable, but also cheap, and widely available on the Earth, preferably non-Nobel metal or his complex.

Copying plants, we can create something like artificial leaf. The function of the matrix is not only to act as a micro bioreactor, but also play role of separation reactants and products (fuel and oxygen). Oxygen is not a desirable product in artificial photosynthesis. Instead of molecular oxygen $\left(\mathrm{O}_{2}\right)$, it can happen that forms oxygen radicals $(\mathrm{O})$, very reactive with strong oxidizing properties. 
With a listed part of the process of artificial photosynthesis, there is only lack of one element - the connector, through which various components interact with each other and create a functional whole.

In order to build a system composed of the described elements, there are carried out intensive research in the USA, Switzerland, UK, Japan and Poland.

The project regarding artificial photosynthesis in Poland started in 2006 at the University of Maria Curie Skłodowska (UMCS) University in Lublin and in collaboration with EKOBENZ company.

The concept of methanol synthesis based on the carbon dioxide formed as a result of different technological processes has been developed by Professor Nazimek from UMCS. The invention is based on the oxidation of water using titanium dioxide $\left(\mathrm{TiO}_{2}\right)$ as a photocatalyst and at the same time the reduction of carbon dioxide (dissolved in $\mathrm{NaOH}_{\mathrm{aq}}$ ). Reaction is carrying out in assistance of fixed ultraviolet radiation (UV) as is shown by reaction 12 .

$$
\left(2 \mathrm{CO}_{2}+4 \mathrm{H}_{2} \mathrm{O}\right)^{\mathrm{hv}} \rightarrow 2 \mathrm{CH}_{3}-\mathrm{OH}+3 \mathrm{O}_{2}
$$

This technology will enable the production of methanol from the two cheap, universal components: carbon dioxide and water vapour. The proposed technology is one of the most promising methods of utilization of $\mathrm{CO}_{2}$, since this compound can be converted to a valuable product, under natural conditions by exposure to UV light.

Implemented technology is characterized by the synthesis reaction of carbon dioxide and water which takes place in aquatic environment at the presence of a photocatalyst at a temperature of $20^{\circ} \mathrm{C}$ and atmospheric pressure. Specifications referred this reaction on a laboratory are shown below:

- Energy consumption $0.75 \mathrm{kWh} / \mathrm{dm}^{3}$ of methanol

- the solution flow rate $8 \mathrm{dm}^{3} / \mathrm{h}$;

- carbon dioxide flow $370 \mathrm{dm}^{3} / \mathrm{h}$;

- the concentration of methanol in the aqueous solution was $15 \%$.

Based on these parameters has been developed preliminary schematic diagram of the planned production process, as shown in Figure 11.

Under the proposed scheme carbon dioxide is stored in the reservoir of raw material from which goes to the mixer where is absorbed in demineralized water. Then, in the reactor under the influence of $U V$ radiation takes place photoreduction reaction. When reaction is completed, the distillation take place and methanol $\left(\mathrm{CH}_{3} \mathrm{OH}\right)$ and water $\left(\mathrm{H}_{2} \mathrm{O}\right)$ are separated. The methanol is sent to the product tank, and the water is reused in the production process - is transfered to the mixer. The active and stable catalyst is the key for obtaining methanol by $\mathrm{CO}_{2}$ photoreduction. For photocatalytic tests were applied $\mathrm{TiO}_{2}$ in the form of anatase supported by alumina as a carrier of the active phase. 


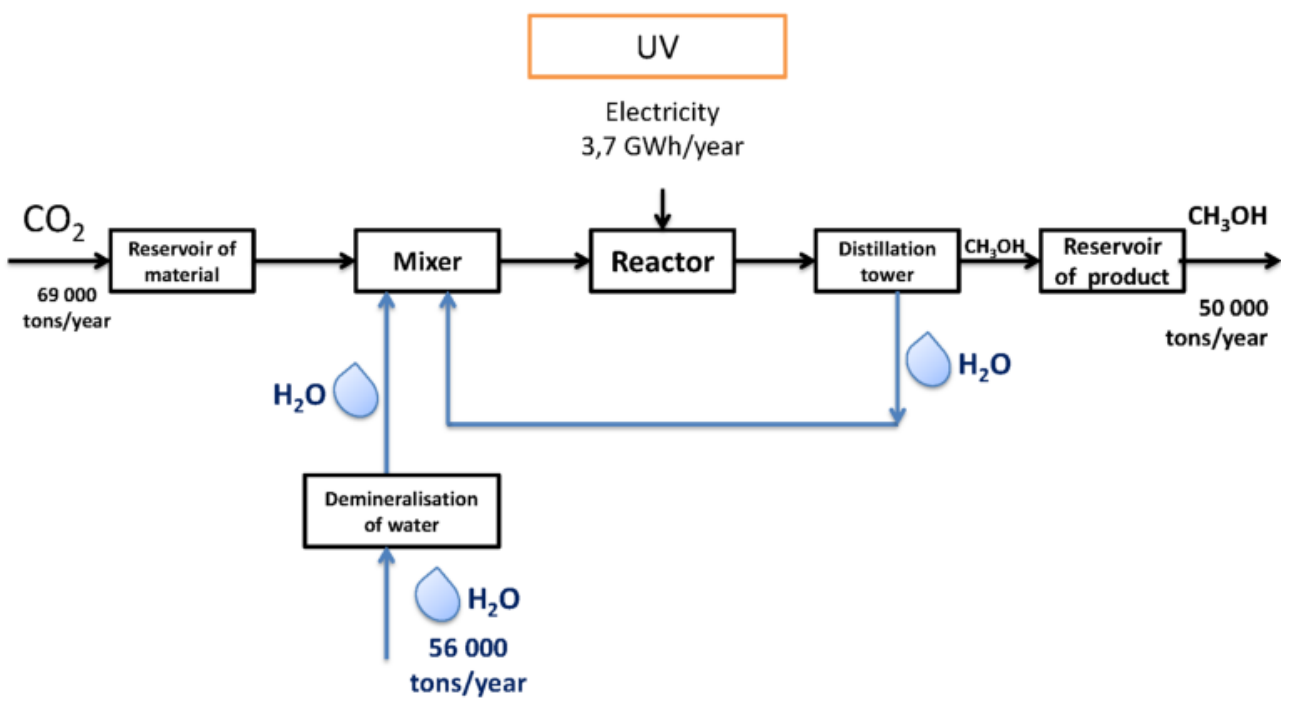

Figure 11. Block diagram showing a manufacturing process of methanol carbon dioxide and water, with the consent of: Ekobenz Ltd

The study at laboratory scale was carried out in flowing system, at atmospheric pressure and ambient temperature, equipped in quartz pipe reactor. In typical experiment $100 \mathrm{~cm}^{3}$ of distilled saturated by $\mathrm{CO}_{2}$, and air or nitrogen flowed through reactor. Bed catalyst was exposed on UV lamp radiation at fixed wavelength. The effluent was analyzed for content of organic compounds by using gas chromatograph. The conversion of $\mathrm{CO}_{2}$ to methanol was determined by the formula (13).

$$
\mathbf{X}(\%)=\frac{C_{0}-C_{1}}{C_{0}}
$$

where: $\mathrm{C}_{\mathrm{o}}$ - initial concentration $\mathrm{CO}_{2}\left[\mathrm{~mol} / \mathrm{dm}^{3}\right]$

$\mathrm{C}_{1}$ - final concentration $\mathrm{CO}_{2}\left[\mathrm{~mol} / \mathrm{dm}^{3}\right]$

The conversion degree of carbon dioxide amounted only $6 \%$ [33]. It was found the titanium dioxide catalyst had a defect in the absorption spectrum, which was located only in the UV light range. Visible radiation even during long-term irradiation was not able to induce the active phase of the pure $\mathrm{TiO}_{2}$. The suspension of titanium dioxide could be the solving the problem, but it is related with separatation of the catalyst from the product liquid phase after reaction completion.

Therefore, the above measurements were carrying out involving a new nano-structured wall catalyst. This catalyst is protected by Polish national patent No. 208030. The catalyst is characterized as the active sites in the form of clusters $\mathrm{TiO}_{3}$ with aluminum III ions and sodium I ions $\left(\mathrm{TiO}_{3}\right.$ content in the range 4.36 to $5.34 \%(\mathrm{~m} / \mathrm{m})$ of the total weight of the catalyst) 
supported by alumina. These clusters are deposited on the inner wall of the aluminum tube of the reactor.

The catalyst described above as the wall form allows to implement an artificial photosynthesis process in the new technology. Developed a new efficient photocatalyst created the conditions for process with performance sufficient for commercial applications, for example by design $0.5 \mathrm{~m}$ length of processing pipe reactor, photocatalysts (with $\varphi=5 \mathrm{~cm}$ ) allowing to convert the $370 \mathrm{dm}^{3}$ of $\mathrm{CO}_{2} / \mathrm{h}$ into methanol with the degree of conversion at $97 \%$.

Figure 12 shows the schematic diagram of the installation for methanol production applying artificial photosyntesis.

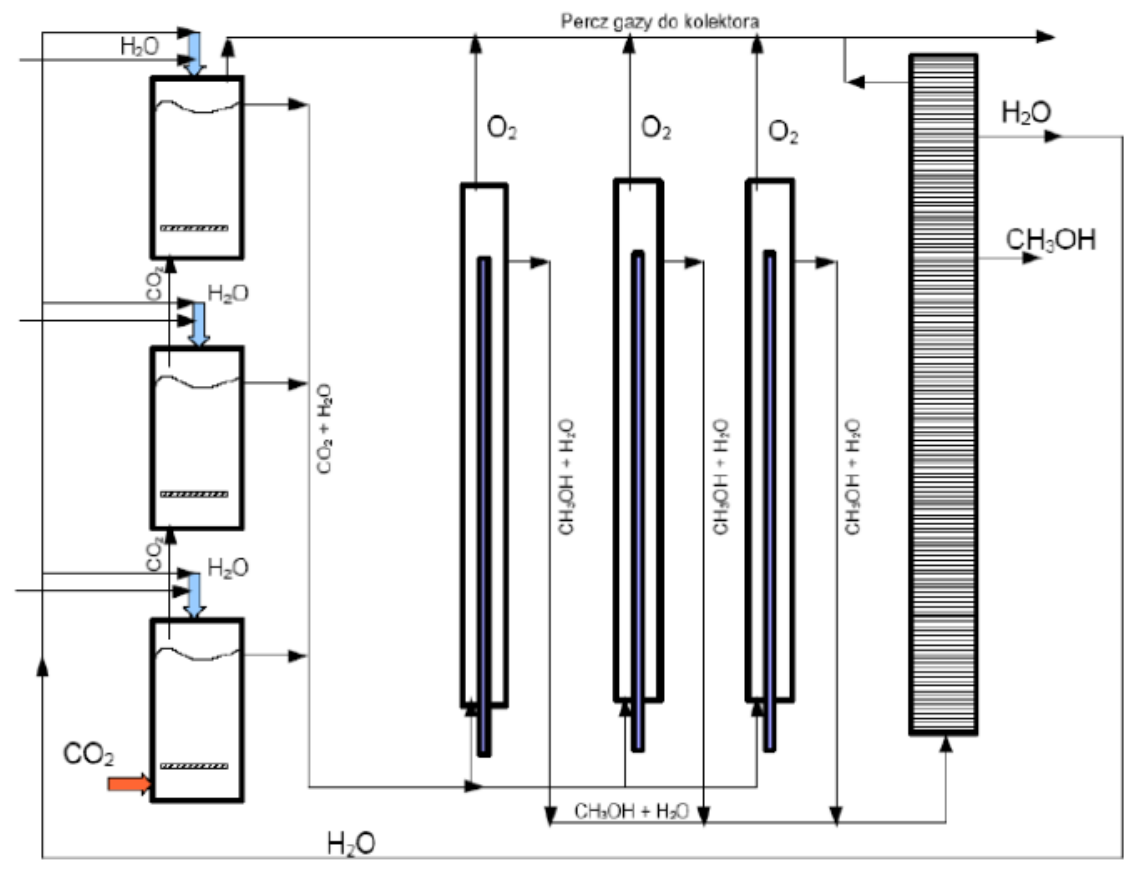

Figure 12. A schematic diagram of the measuring system for the production of methanol in the artificial photosynthesis, with the consent of: Ekobenz Ltd

As shown in Figure 12 carbon dioxide with water are transfered into mixers arranged in series, which supply the reactors system. The catalyst is located on the reactor walls, as a result of reaction are products like oxygen molecule, water and methanol. Molecular oxygen is discharged to the gas collector, and the mixture of methanol and water is further transferred into the distillation tower, where separation these compounds take place. Water is returned to the mixer, where it is used in the subsequent cycles of the process, and desired the final product is separated as a pure methanol. 
The methanol obtained through the described technology can be directly applied as a fuel in dedicated engines and adjusted fueling systems with seals, proper polymer pipes because methanol is known as a good solving agent for many materials used in cars now. On the other hand methanol can be catalytically converted towards gasoline fraction by using very well known from 70's Mobile process- MtG (Methanol to Gasoline). MtG method involves the synthesis of a higher hydrocarbons mixture (which are synthetic petrol) from methanol, the intermediate product according to the general reaction (14) are:

$$
\mathrm{nCH}_{3} \mathrm{OH}\left(\text { zeolite catalyst eg. ZSM-5) } \rightarrow \mathrm{C}_{\mathrm{n}} \mathrm{H}_{\mathrm{n}+\mathrm{x}}+\mathrm{H}_{2} \mathrm{O}\right. \text { * }
$$

*The $\mathbf{n}$ and $\mathbf{x}$ values are variable depending on the temperature and pressure in the system, as well as catalyst used in the process.

Reaction (14) occurs at a temperature $\mathrm{T}=723 \mathrm{~K}$ and under the pressure of $\mathrm{p}=200$ bar. Water is a by-product of the reaction is, which is a limiting factor in MtG synthesis because it affect the catalyst performance. The catalysts used in the synthesis of synthetic gasoline from methanol are based on aluminosilicate matrix. These type of catalysts in some excess of water vapour, in the reaction mixture, lose their activity because of extraction for example $\mathrm{Al}$ ions from the matrix of catalyst. A new catalyst has been developed, which is water-resistant in the reaction mixture used in MtG method as well as related technology EtG (ethanol to gasoline, which will be discussed later in this chapter). Nano-structure catalyst developed for the synthesis of gasoline from the ethanol according to equation (14) is characterized by the active centers in the form of a copper ions coordinated in octahedral structure. Copper is supported by nanostructured aluminosilicate matrix with metal content in the range of $0.2-0.5 \% \mathrm{w} / \mathrm{w}$. This catalyst has a high water resistance with content even more than $10 \%$ water by volume of the reaction mixture.

The final product of the described method MtG is appropriate mix of higher hydrocarbons, which are synthetic gasoline with an octane rating of up to 108 , characterized by the same properties as gasoline derived from crude oil processing. Summary of the final products of described MtG method is shown in Table 5 [34].

Gasoline - until $108 \mathrm{LOB}(\mathrm{Q}=44,8 \mathrm{MJ} / \mathrm{kg})$

ON - 56 cetane number

SNG $\left(\sim 95 \% \mathrm{CH}_{4}\right)$

aromatic fractions

Table 5. Summary of the final products of the MtG technology

According to preliminary estimates, this method is able for application within three years, and what is most important can cause the reduction of $\mathrm{CO}_{2}$ in the atmosphere by $25 \%$. 
Some inaccuracies in the calculation of the energy balance above process should be noted. The synthesis of methanol from $\mathrm{CO}_{2}$ and $\mathrm{H}_{2} \mathrm{O}$ is endothermic reaction, which means that for the occuring reaction is required determined amount of energy. It was found out, the total power consumption in order to obtain a $1 \mathrm{dm}^{3}$ methanol is $0.75 \mathrm{kWh}$. The balance of energy showed the following conclusions:

if: 1 kilomole of $\mathrm{CH}_{3} \mathrm{OH}=586 \mathrm{MJ}$

1 kilomole of $\mathrm{CH}_{3} \mathrm{OH}=32 \mathrm{~kg}$

therefore: $32 \mathrm{~kg} \mathrm{CH} 3 \mathrm{OH}=586 \mathrm{MJ}$

Then $1 \mathrm{~kg} \mathrm{CH} \mathrm{CH}_{3} \mathrm{OH}$ is:586 MJ / $32 \mathrm{~kg}=18.31=5.08 \mathrm{kWh}$

specific weight $\mathrm{CH}_{3} \mathrm{OH}$ is: $0.48 \mathrm{~kg} / \mathrm{l}$.

therefore: $1 \mathrm{~kg}=5.08 \mathrm{kWh}$, which gives $0.48 \mathrm{~kg}(=1$ liter $)=2.44 \mathrm{kWh}$

Conclusion: To make 1 liter of methanol from $\mathrm{CO}_{2}$ and $\mathrm{H}_{2} \mathrm{O}$ is required $2.44 \mathrm{kWh}$, it is three times higher than reported by the inventor of the method $-0.75 \mathrm{kWh}$.

Therefore, the cost obtaining of 1 liter methanol will be about 0.31 USD, and not as referred value 0.03 USD [35]. Regardless, a drawback of this method is the fact the developing technology is based on the pure components. In the synthesis reaction of the methanol with carbon dioxide and water, is used $96.5 \% \mathrm{CO}_{2}$ from the pressure cylinder, which occurs very rarely, only in some chemical processes (including fermentation). The effects of using carbon dioxide mixed with air in the reaction, such as is found in the nature, wasn't fully investigated yet.

In summary, the method of converting carbon dioxide into methanol at the moment is not applicable, because there is no beneficial economic and energy effects. For these reasons, the project in methanol synthesis in the process of photoreduction of carbon dioxide was suspended. The chance for this interesting project is replacing artificial sources of UV radiation by the natural sunlight. Then the project possibly would be cost and energy-effective. It depends on the active catalyst that would work efficiently in the visible light range.

The part of the project under investigation is still EtG process (Etanol to Gasoline). The coupling process of ethyl alcohol towards of higher hydrocarbons also take place with a suitable zeolite catalyst, at higher temperature and pressure. Replacing ethanol by its homologue methanol causes a significant reduction of pressure required for a reaction, from about 200 bar to 30 bar. Also, the temperature is much lower and amounts $653 \mathrm{~K}$ [36]. Reaction of ethanol conversion into higher hydrocarbons is exothermic, and therefore there is a problem with removal of the heat. if combined with endothermic process of methanol synthesis could improve the energy balance of carbon dioxide conversion into methanol. The tubular reactor is cooled at the moment by medium, which at the beginning of the research was air. Now it was changed to a more efficient oil. This method of catalyst cooling is not very effective, because it reduce the temperature only near the outer wall of the reactor. The gradient temperature within radius can reach the temperature up to $300{ }^{\circ} \mathrm{C}$. Then, the catalyst located in the center of the reactor can be affected by sintering process, and then lose activity. The current research aim is to 
optimize the temperature of the entire length of the reactor, to avoid deactivation of the catalyst.

At the present stage of research, the experiments are carried out in one reactor, and the target is to operate six reactors cooperating with each other, forming so-called hexagonal reactor. The overall diagram of the EtG is shown on Figure 13.

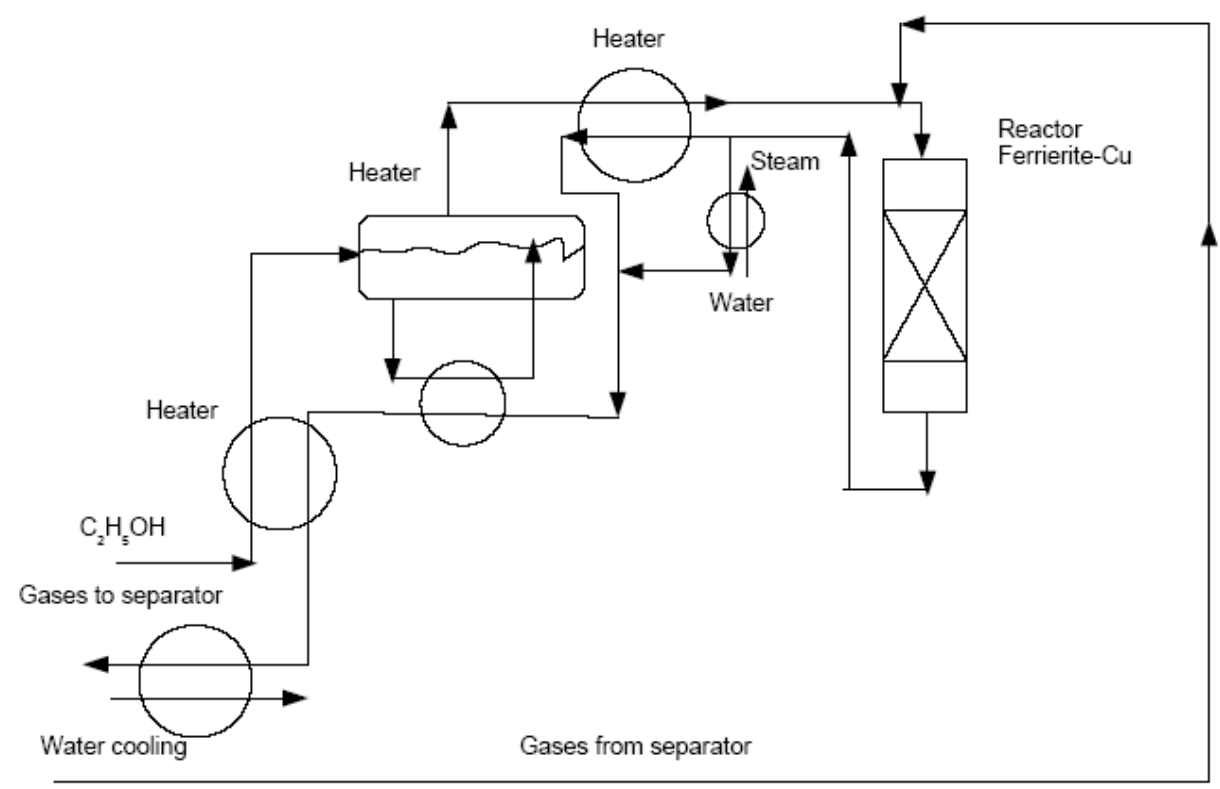

Figure 13. Diagram of the research installation for the process EtG, with the consent of: Ekobenz Ltd

Under the pictured diagram, ethyl alcohol is sampled into the heater, where in the electric heater spiral is heated to about $270{ }^{\circ} \mathrm{C}$, and through the isolated pipes reaches the reactor. Outlet reaction mixture flows to the condenser, where the liquid products are out dropped. However the ethanol is converted not only towards the liquid fraction, but as a result of this reaction the gaseous products are also formed. Gases are recycled to the reactor, mixed with a new part of ethanol steam and are converted into gasoline fraction. The liquid fuel is further analyzed from point of view requirements of gasoline and diesel. The typical content of such products are benzene (as aromatization compound of ethanol on zeolite), olefins, paraffins and other aromatics. Research in this area is continued in Poland on the frame of "Operational Programe of Innovative Economy". The process is called ETG (ethanol to gasoline) is similar to the MTG (methanol to gasoline) process which was successfully used by Methanex in New Zealand. 


\subsection{Photoconversion technology using "artificial leaf"}

On 241 Congress of National Meeting of the American Chemical Society in Anaheim, Califfornia, it was announced the invention of the first functional artificial leaf. "A practical artificial leaf has been for decades the one of the Holy Grails of the science" - said the leader of the team, Dr. Daniel Nocera - "We believe that we did this" [37].

A breakthrough moment in the study of artificial leaf is development of a suitable catalyst, nickel (Ni) and cobalt (Co). These elements are widely available comparing with noble metals, what is important they act at ambient conditions and have a high stability during the reaction. Inventor reported very effective work of artificial leave for production hydrogen and oxygen.

The artificial leaf is a matrix composed of material used in most of the solar cells, semiconductor silicon. Surface is covered with a matrix of cobalt catalyst on the one side, and on the other side with the molybdenum-zinc alloy of nickel. Solar radiations falling on the surface are transformed into electricity which allow to decompose bond of water molecules in the presence of catalyst. On the first side of the matrix, the electrons are knocked out from the water molecules using cobalt catalyst. The water molecule is decomposed into hydrogen ions $\mathrm{H}^{+}$and oxygen. Oxygen remains on first this side of the membrane, while the hydrogen ions are transported to the other side of the matrix, where the nickel is catalyzing the recombination reaction of hydrogen ions with the previously made free electrons. The result of the process is $\mathrm{H}_{2}$ molecules formation [37-40]. Diagram of the act "artificial leaf" is shown in Figure 14.

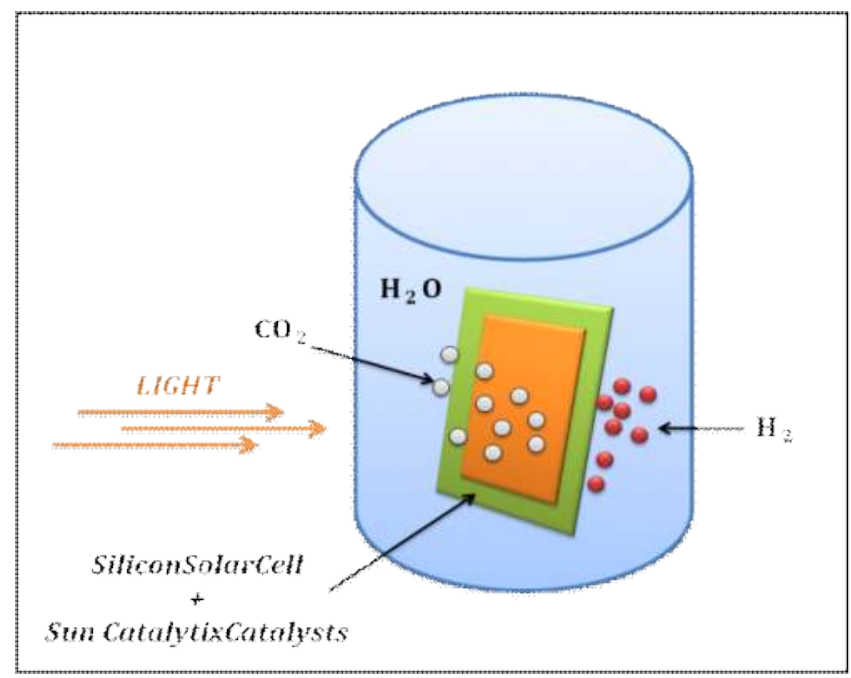

Figure 14. Diagram of the artificial leaf [38 modified]

In this way, as it is shown in Figure 14, one surface of an artificial leaf produces oxygen and the other - hydrogen. 
According to data the authors team, with one gallon of water, exposed to solar radiation using artificial leaf; it is possible to produce enough electricity required for the daily demand for household energy in developing countries.

\subsection{Solar reactor in technology of synthesis gas getting (,solarfuels")}

The research group of CalTech from United States published in December 2010 the paper regarding their latest achievement in artificial photosynthesis. Prototype solar device was constructed, where the heart of device is cerium dioxide $\left(\mathrm{CeO}_{2}\right)$ catalyst. Diagram of the device is shown in Figure 15.

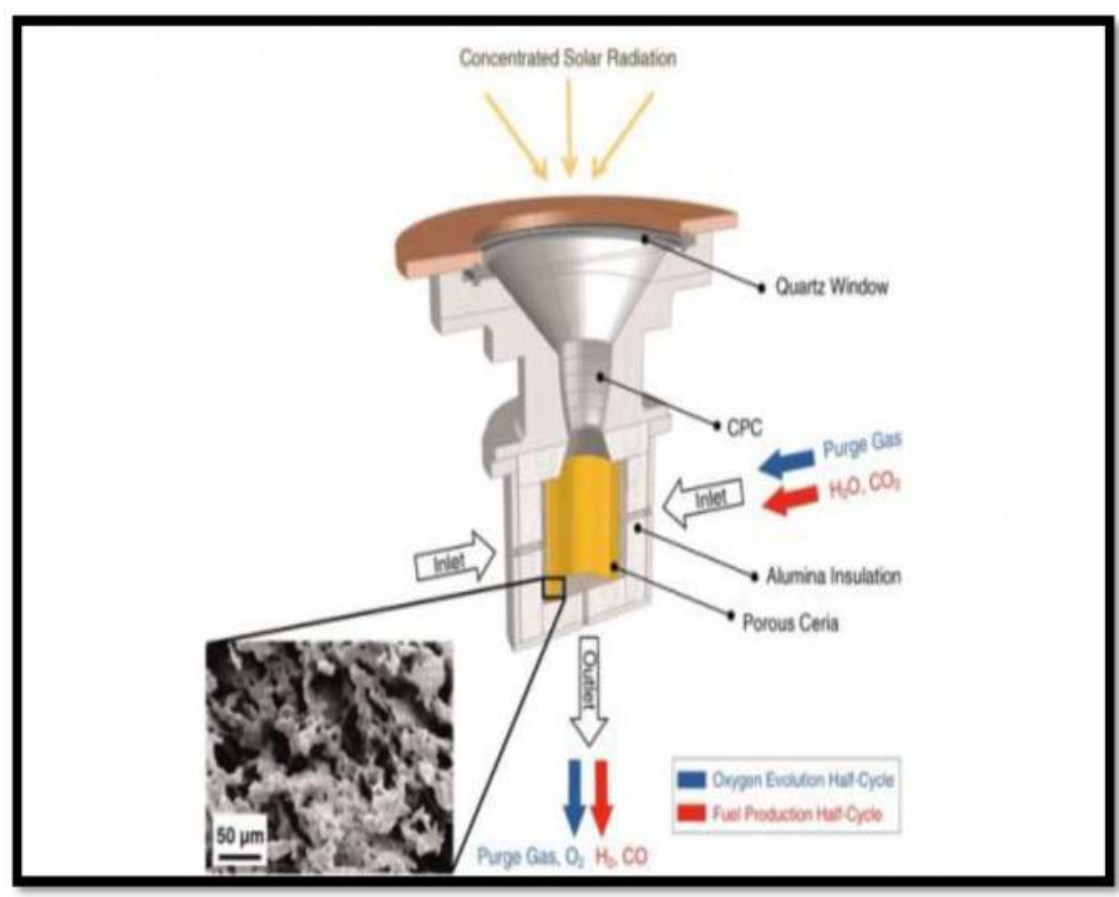

Figure 15. Prototype reactor uses the sun to produce storable hydrogen fuel [ 41 modified]

Reactor operation is based on the absorption of concentrated solar radiation, which falls on a quartz apparatus window, then passes into the insulated chamber of the receiver, which is filled with a porous cerium oxide. This compound has a specific property of the oxygen binding at low temperatures, and desorption it at high temperatures, without damage of its crystalline structure, according to the reactions (15), (16), and (17).

$$
1 / \mathrm{n} \mathrm{MO}_{2} \rightarrow 1 / \mathrm{n} \mathrm{MO}_{2-\mathrm{n}}+1 / 2 \mathrm{O}_{2(\mathrm{~g})} \mathrm{T}_{\mathrm{H}}
$$




$$
\begin{aligned}
& \mathrm{H}_{2} \mathrm{O}_{(\mathrm{g})}+1 / \mathrm{n} \mathrm{MO}_{2-\mathrm{n}} \rightarrow 1 / \mathrm{n} \mathrm{MO}_{2}+\mathrm{H}_{2(\mathrm{~g})} \mathrm{T}_{\mathrm{L}} \\
& \mathrm{CO}_{2(\mathrm{~g})}+1 / \mathrm{n} \mathrm{MO}_{2-\mathrm{n}} \rightarrow 1 / \mathrm{n} \mathrm{MO}_{2}+\mathrm{CO}_{(\mathrm{g})} \mathrm{T}_{\mathrm{L}}
\end{aligned}
$$

where: $\mathrm{M}$ - pure cerium or cerium with mixtures; $\mathrm{T}_{\mathrm{H}}$ - at high temperatures; $\mathrm{T}_{\mathrm{L}}$ - at low temperatures [42]

In this way, it absorbs oxygen gained from supplied to the reactor carbon dioxide $\left(\mathrm{CO}_{2}\right)$ and water vapor $\left(\mathrm{H}_{2} \mathrm{O}\right)$. Thus, inside the reactor are formed the carbon monoxide $(\mathrm{CO})$ and hydrogen $\left(\mathrm{H}_{2}\right)$, which is an ideal source of energy. Hydrogen is considered to be so-called "clean fuel" because in the result of its combustion the water is just produced. However, the reaction of hydrogen with carbon monoxide if presented by stechiometric reaction can be directed towards methane formation, popular heat, transport fuel and source of chemicals production (reaction 18). The synthesis gas in proper molar ratio of $\mathrm{CO} / \mathrm{H}_{2}$ and using FT catalyst (Co or bimetallic with $\mathrm{Fe}$ ) can be converted towards higher hydrocarbons.

$$
\mathrm{CO}+3 \mathrm{H}_{2} \leftrightarrow \mathrm{CH}_{4}+\mathrm{H}_{2} \mathrm{O}
$$

In the CalTech process the reactor was exposed to solar radiation at $1.9 \mathrm{~kW}$ of power. Such power is widely used in various types of solar antennas or solar towers; any of these devices has not reached the efficiency of the presented prototype. This can be explained by the fact, the reactor uses the entire spectrum of light, not only the selected wavelength. Disadvantages of the presented solar reactor is the energy losses as a result of energy radiation through the walls of the reactor (about $50 \%$ of the energy input) and the release of radiation through the quartz window (about $41 \%$ of supplied energy).

It can be assumed that further improvement of the process will be able to reduce the temperature of the reactor (today reactor operates at $1648{ }^{\circ} \mathrm{C}$ ), and less energy losses through more efficient use of solar radiation. An initial analysis of the process effectiveness showed that improvements structure of cerium oxide will allow to increase activity of catalyst in the range of $16-19 \%$.

This concept can be used for conversion carbon dioxide emitted from coal power plant to liquid energy carriers. The pure carbon dioxide is not required to carry out this reaction. This allows at least twice using of the same coal compund [42].

\subsection{Biological processes using carbon dioxide as a raw material}

As stated previously, the world's biomass resources are not enough for producing renewable energy with at the same time growing needs of modern civilization. For example in UK, replacement of diesel by biodiesel produced from rapeseed would required plantation more than half area of the country [43]. The areas for the production of liquid biofuels is competitive with the same areas for the cultivation of food crops. There is a conflict between energy and 
food use of agricultural land. In addition, oilseeds cultivation leads to monocultures over large areas, which is inconsistent with the Directive 2009/30/EC. As stated in mentioned Directive production of biomass for energy purposes should go hand in hand with biodiversity. Nowadays more and more we hear about a new raw material for the production of liquid fuels which can be tiny microorganisms such as algae. Algae growing is a good option for limited areas of cultivation of biomass for energy purposes. Algae can be grown in areas not suitable for the cultivation of the soil, such as deserts or oceans. In addition, they are a kind of "factory", able to convert waste carbon dioxide into valuable energy products.

The idea of using algae as a feedstock for bioenergy production has already appeared in the mid-twentieth century. In 1940, it was discovered that many species of microalgae growing in strictly definite conditions can produce large quantities of lipids. The concept of using the stock of lipids as an energy source has been caused by the oil crisis which arose from the imposition of the embargo in 1973 by the OPEC countries. The rapid increase in oil prices and the reduction of the energy carrier from Middle East to the United States contributed to the search for new sources of energy such as micro-algae. In 1978, Program of the Department of Energy for Aquatic organisms have been created (DOE's Aquatic Species Program), which focused on the acquisition of the fuel in the form of pure hydrogen supply by aquatic organisms. Already in the early 80 's, this was changed and focused on trying to manufacture liquid fuels, mainly biodiesel. Over 300000 existing algae strains were collected from different extreme environments. The next seven years were carried out research regarding tolerance of different salinity on temperature, $\mathrm{pH}$, and the ability for the production of neutral lipids. After these tests, the study was limited up to 300 promising strains, in which the main role was played: diatoms algae (Bacillariophyceae), and green algae (Chlorophyceae) [44].

Algae are a valuable source of raw material for energy transformation because of fast growth of the biomass. Autotrophic algae contain chlorophyll molecule in their cells so they have the ability to carry out the process of photosynthesis. They are able to use about $10 \%$ [45] of the sunlight falling on it, in consequence able to double their weight during the day, and in the experimental conditions this time was reduced up to 3.5 hours [46]. The study shows that wit hin one year cultivation of algae on the area of one hectare, it is possible to get 8,200 liters of biodiesel from extracted algae lipids, while for other oleic plants like jatropha only 2700 liters, 1560 liters from canola, and from soybean only 5441 [43]. These data are summarized in Table 5.

\begin{tabular}{cc}
\hline Crop & Biodiesel yield (L/ ha/ year) \\
\hline Oilseed rape & 1560 \\
\hline Soya & 544 \\
\hline Jatropha & 2700 \\
\hline Chlorella vulgaris & 8200 \\
\hline
\end{tabular}

Table 6. Estimation of oil productivity from different crops [43] 
According to the literature, the production algae biomass is $40 \ldots 60$ times higher than previously cultivated energy crops. The yield estimated with different cultures growing algae in closed photo bioreactors is about $(400 \ldots 500) \mathrm{Mg} / \mathrm{ha} / \mathrm{y}$, which coresponds (400... 500) thousand $\mathrm{m} 3$ of bioethanol per year [47].

Another advantage is that algae cultivation is possible in wide variety of water sources: seawater, postproduction water, as well as in wastewater.

One of the key reasons to use algal biomass for energy purposes is these microorganisms absorb and convert a significant amount of residual carbon dioxide. To provide $100 \mathrm{~g}$ of biomass, algae consume about $183 \mathrm{~g}$ of carbon dioxide, which is associated with a $50 \%$ share of $\mathrm{CO}_{2}$ in dry weight of these microorganisms [48]. With the ability to bind $\mathrm{CO}_{2}$ algae opens the possibility of using waste carbon dioxide from the exhausted gase, for example coal-fired plants. In this way, they close the circulation of carbon in nature. They also show the ability to absorb other waste components, such as nitrogen or phosphorus for example from of chemical fertilizers. With this ability algae can lead the process of bioremediation of contaminated environments, thus contributing to reduce contamination of soil or surface waters (eutrophication) and groundwater.

Energy sources that can be produced from algae depend on the substrate used and the method used to process the obtained algae biomass. The main path of bioenergy production using algae is shown in Fig.16.

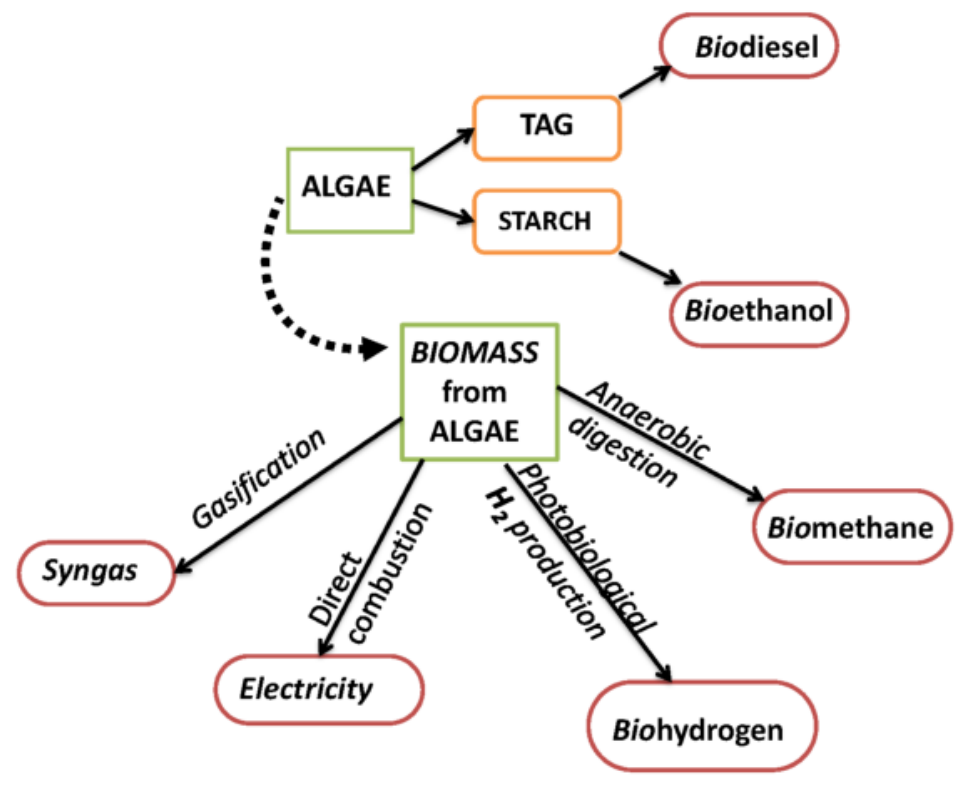

Figure 16. Path of bioenergy produced by using algae. 
As shown in Figure 16, we can get bioenergy directly from algal biomass include electricity, syngas, biohydrogen and biomethane. However, two main liquid energy carriers gained from the cultivation of algae are biodiesel and bioethanol.

For the production of biodiesel from algae, the most important is choosing the right kind of algae for triacylglycerols (TAG) obtaining as well as made the ideal cultivation system of these microorganisms. It is necessary to use not only the knowledge of the bioenginering of the various strains of algae, but also integrate this knowledge with the best matching further process technologies [44].

It was observed that in the optimum conditions for the development of algae, which is a sufficient amount of nutrients (such as nitrogen and phosphorus) biomass increase, but the percentage of the dry weight of TAG is rather small. For example for the species Chlorella Vulgaris it is about $14-20 \%$ of TAG. However, in the lack of nutrients, algae forms a reserve of energy in the form of so-called TAG. The percentage of TAG per dry mass for Chlorella Vulgaris reaches up to $70 \%$, when nutrition substances are limited. One proposed solution for this phenomenon is a two-step process of algae cultivation. It is based on the fact that in the first stage of breeding algae grown in optimal conditions, with a sufficient amount of nutrients, which results in a rapid increase of their dry biomass. In the second stage the algae are transferred to the place with significantly reduced amount of nutrients. So these micro-organisms, as they are stored in a nutrient deficient conditions lead to increased production of TAG cells.

Another solution is to use microtrophic algae. They are characterized that under conditions of sufficient amounts of nutrients, mainly easily assimilable carbon such as glucose, are transferred to the heterotrophic mode during which produces significantly greater amounts of lipids. Unfortunately, by introducing additional nutrients such as glucose, this solution entails the risk of contamination algae culture by heterotrophic fungi and bacteria [49]. Moreover, one of the main advantages of using algae for biodiesel production is the use of carbon dioxide from the combustion of fossil fuels.

Properly grown biomass is collected and processed in such a way to maximize the production of triacylglycerols cells for the production of biodiesel (Fig. 17).

Algae farm is usually isolated as was shown in Figure 17. In order to reduce the water content, of the harvested biomass, is added the flocculant. Lipid fraction extraction take place with help of hot diesel fuel, than the mixture is separated by using centrifudge.The oil fraction is separated from the watery phase and the biomass waste. Oil fraction can then be used in transesterification reaction to produce FAME or synthetic hydrocarbons using HDO process. As a result, from showed processes already are produced fuels by Sapphire Energy, Petroalgae and Solix Biofuels.

For example, an American company Sapphire Energy in 2008 has successfully produced 91octane gasoline from algae, which complies with U.S. standards. They made a flight test with the twin-engine Boeing using algae-based jet fuel in 2009. They started the construction of an integrated minibiorefinery based on biomass from algae in the southern part of the state of New Mexico in 2010 (called Intergrated Algal Bio-Refinery) [50, 51] 


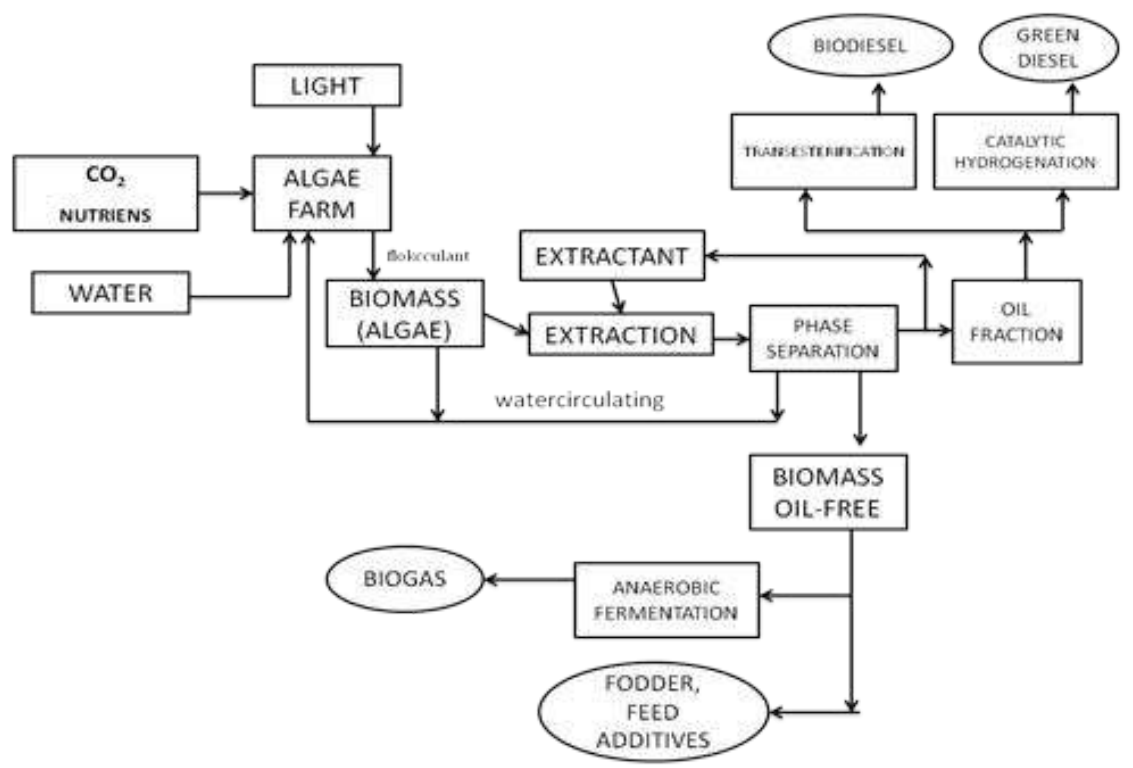

Figure 17. Schematic diagram of the fuel receiving a "biodiesel" from algae [45]

In the process of producing ethanol from starch contained in algae cells, the most plentiful in this hydrocarbon algal classes are: Chlorophyceae (green algae) of the types: Chlamydomonas and Chlorella and Cyanophyceae of species: Arthrospira, Oscylatoria and Microcystis. Bioethanol from the sugar gained from algal biomass can be obtained by:

- Breeding of certain species of algae in anaerobic and without the sun conditions (then the algae produce ethanol within the extracellular space);

- Extraction starch from algal cells and then, through the enzymatic hydrolysis and fermentation ethanol is produced [45].

For example, patented by the company Algenol Biofuels process is called Direct to Ethanol $®$ and is based on breeding of algae Cyanophyta in specially designed flexible plastic photobioreactors. Using seawater and waste carbon dioxide (fed directly from industrial plants) and subjected to direct sunlight, the algae perform photosynthesis. Sugar molecule (starch) get by photosynthesis process is fermented to ethanol, which diffuses through the cell walls of algae to the solution of breeding. Because of raised temperature during the day, ethanol is evaporated from the solution. On the inner wall occurs condensation of ethanol vapors when the temperature decrease at night outside of photobioreactor,. The condensate drops down of the reactor, where on special internal basins is collected and transferred to distillation unit.

Except lipid molecules in the form of triacylglycerols, or hydrocarbons in the form of starch, which are precursors for the production of biofuels, from algae biomass may be obtained also other products such as proteins. Therefore, in the production of biofuels using algae is formed 
a wide range of products such as animal feed, fertilizers, pigments, bioplastics, detergents, cosmetics and even food [52].

\subsubsection{Offshore membrane enclosures for growing algae - OMEGA system}

OMEGA technology, originally developed by NASA, is derived from the space program aimed to closing the loop (called "close the loop") between the waste stream and the resources necessary for astronauts during long flights [53]. The modified system is to grow cultures of algae in specially designed, floating on the water surface, photobioreactors (PBR) composed of polymers. On the figure 18 is presented the idea of this system.

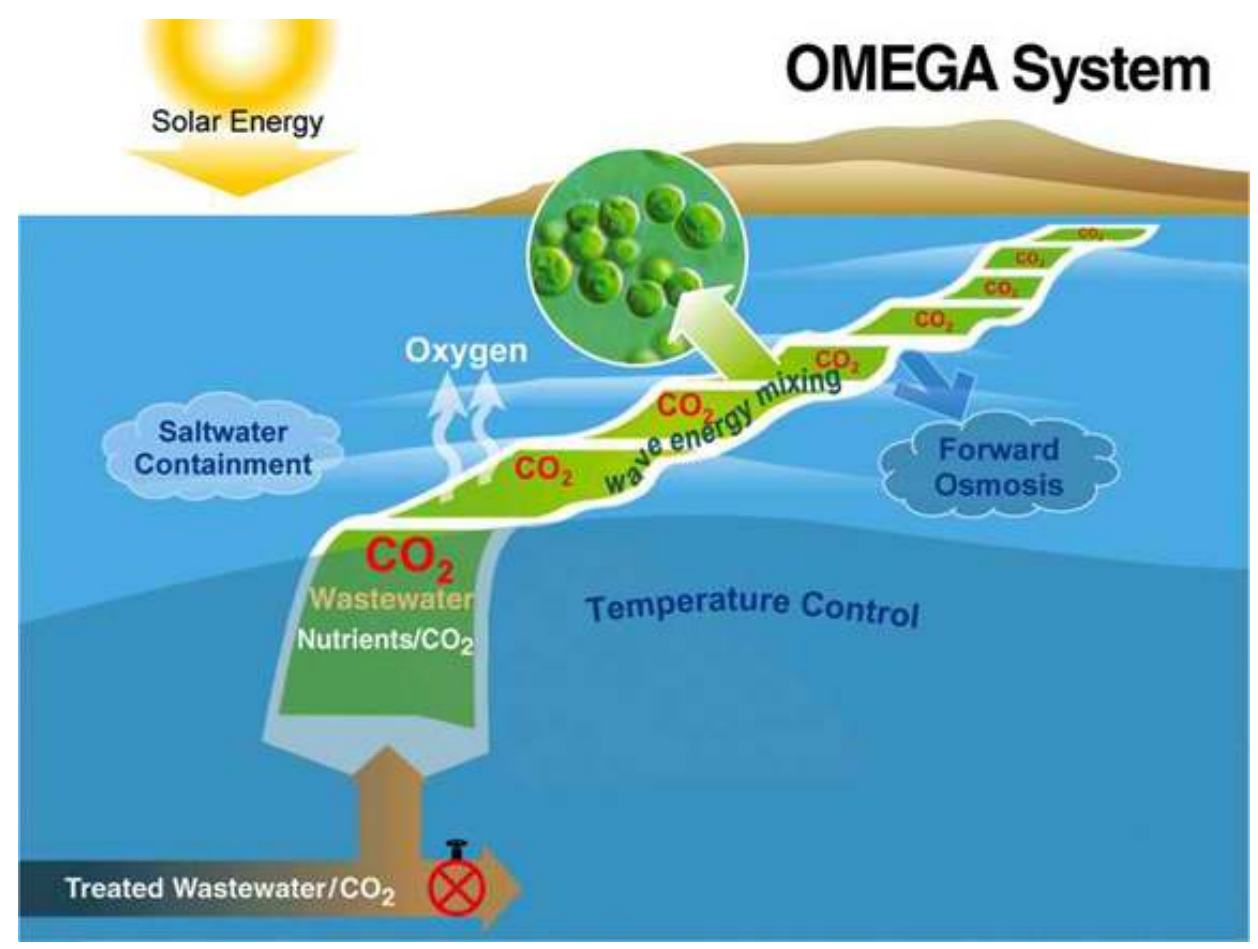

Figure 18. The OMEGA System [54], with the consent of: Jonathan Trent

The system consists of a number of connected, floating photobioreactors, which are pumped by waste water from the mainland (the actual appearance of the plastic photobioreactors "bags" floating on the water are shown in Figure 19). 

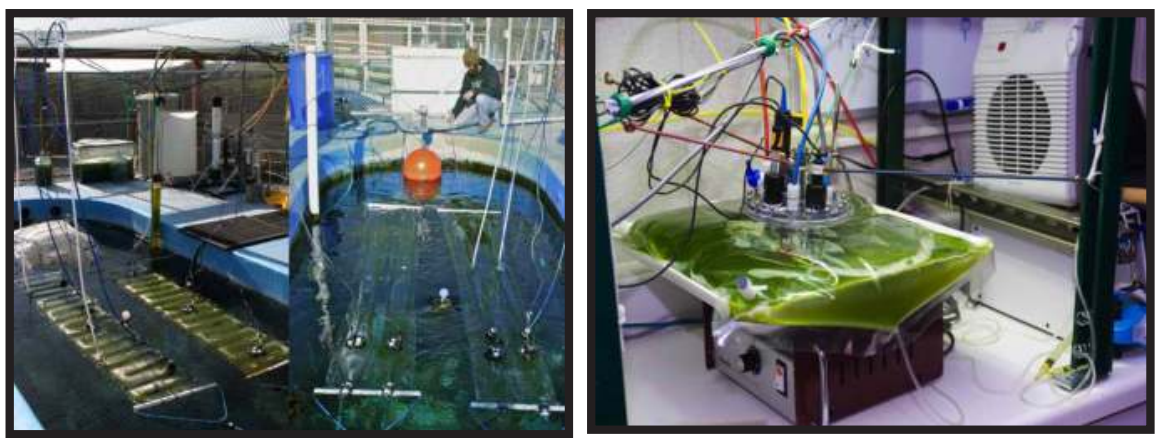

Figure 19. Examples of prototype photobioreactors for technology OMEGA System [54], with the consent of: Jonathan Trent

Algae consume nutrients contained in the sludge, and they associate the carbon dioxide from the air, or waste $\mathrm{CO}_{2}$ emitted directly from industrial gas plants. By using solar energy, they embed $\mathrm{CO}_{2}$ into their cells and give off the oxygen into the atmosphere, at the same time producing biomass and oils in their cells. The temperature inside the photobioreactor is controlled by the heat capacity of the surrounding ocean waters, and the gradient between the wastewater and seawater was used for the drainage of photobioreactors. In case of leak the photobioreactor content into the ocean, freshwater algae are breaking up, because they are not able to survive in saltwater. These biochemical species of algae are decomposed into simpler chemical compounds. Thus sea water where are mounted plantations algae are not contaminated. The algae after the growing phase are transfered into the osmotic chamber to make them more dense. Then biomass material is transported into a collection chamber, from where are send to biorefineries. Waste water is returned to the cultivation unit, to maintain the adequate stock and optimum concentration of nutrients for carry out the photosynthesis process by algae. The OMEGA technology final products are biodiesel, jet fuel and by-products such as cosmetics, fertilizers, and animal feed.

The method of producing biofuels using microorganisms is an agree with the nature. There is not used genetic modifications organism and the risk of GMO species invasion into the natural sea environment. Strains of algae are biodegradable, which means it does not involve any risk of pollution of the seas, and oceans, and may even provide food for fish living there. The only added cost is the pumping wastewater into the photobioreactor. However, it was showed the idea of driving the process using wind turbines or solar panels [54, 55].

\subsection{Processes of sunless photosynthesis}

Term of sunless photosynthesis may be used to define the process carried out by heterotrophic algae without the solar energy, but using the previously synthesized organic compounds as a source of carbon and energy. 
Heterotrophic algae growth is dependent on many factors. A significant role in the stimulation or inhibition of heterotrophic microorganism's growth will play the access of sources organic compounds. Depending on the concentration as well as the amounts of organic compounds in a given nourishment, the algae biomass growth runs with different efficiencies. It was also found the positive effect on the growth of microorganisms in environment with poor carbon source mixture. Another factor that has an impact on the growth of algae biomass is the concentration of nutrients such as nitrogen. For example, the studies show the most effective source of nitrogen for the growing of microorganisms on the glucose nourishment is urea [56]. One of the companies dealing with the issue of sunless photosynthesis of algae on an industrial scale is a private company Solazyme Inc., which was found out in 2003. Method for waste biomass change-over to liquid fuels, developed in the company, uses various strains of heterotrophic genetically changed algae to produce different types of fuels. Figure 20 shows the main production pathway in Solazyme technology:

\section{Renewable Oil Production Process}

up to $95 \%$ reduction in $\mathrm{CO}_{2}$ versus fossil fuels

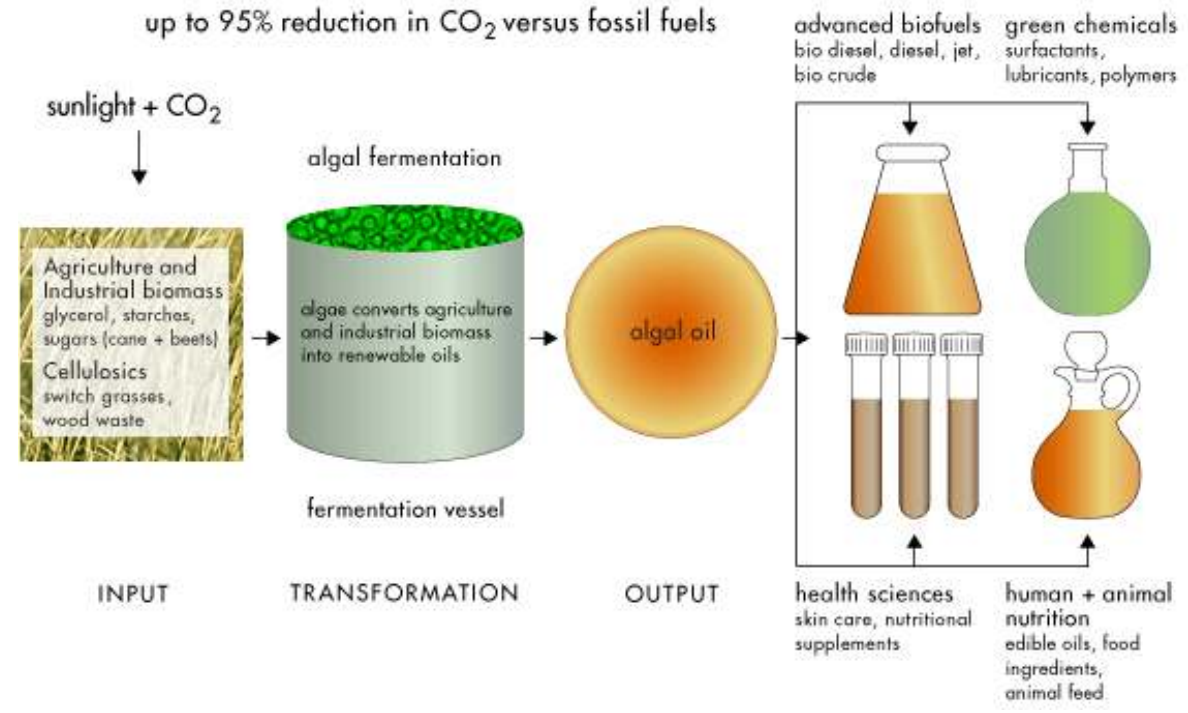

Figure 20. Schematic diagram drawing the production process of different industrial products by Solazyme technology [57]

Alpha Algae, used by Solazyme, are heterotrophic organisms, which means they are developing without solar energy. Identified strains of algae, as it was shown in Figure 20, are transferred into the stainless steel containers. There, in darkness algae are fed by nourishment 
in the form of various types of raw material. This is mostly lignocellulosic biomass, so all kinds of grass, wood chips, agricultural sludge, as well as other waste substances. Depending on the type of nourishment, and the breeding strain, the algae produce different products. Some of them produces lipids, others provide a rich mixture of hydrocarbons, similar to those included in the light oil [58].

The biggest achievement of California's company happened on 13 March 2012. The ship LM 2500 fleet of U.S. Navy frigate, sailed successfully from the port in Everett (WA), to San Diego (CA), powered by fuel: Soladiesel HRD-76 @. The ship was driven using 25,000 liters of 50/50 mixture of Soladiesel $\AA$ and pertoleum F-76. That was the first ever demonstration of alternative fuel mixture in the ship of naval fleet [59].

\section{Biohydrogen and Liquid Organic Hydrides ( $\mathrm{LOH})$ application}

In the context discussed above solar fuels effective production of hydrogen could be the chance for application of $\mathrm{LOH}$ as chemical hydrogen storage medium.. The use of liquid organic hydrides in hydrogen storage provides high gravimetric and volumetric hydrogen density, low potential risk, and low capital investment because it is largely compatible with the current transport infrastructure, see Fig.21. Despite its technical, economical, and environmental advantages, the idea of hydrogen storage in liquid organic carriers has not been commercially proved yet. This is because of technical limitations related to the amount of energy required to extract the hydrogen from liquid organic hydride and dehydrogenation catalyst is not stable enough. Renewable hydrogen as well aromatic compounds can be obtained by direct catalytic conversion of methane or biomethane in dehydrocondensation (DHC) reaction. DHC processwas intensively was studied for the last decade by several groups of researchers, mostly from Japan [60-63], China [64], USA [55-67], and Hungary [68]. Following endothermic reaction represents methane direct conversion to benzene and hydrogen without participation of oxygen:

$$
6 \mathrm{CH}_{4} \Leftrightarrow \mathrm{C}_{6} \mathrm{H}_{6}+9 \mathrm{H}_{2}, \quad \mathrm{DH}_{298}=88,4 \mathrm{~kJ} / \mathrm{mol}
$$

The most effective catalyst for this process is Mo/H-ZSM-5 and Re/H-ZSM5. Oxygen-free conditions used for this reaction result in high benzene selectivity (up to 80\%). Nowdays, methane is mostly used for heating purposes, as a transport fuel (CNG) and for chemical synthesis. DHC is promising process from point of view petrochemical feed stocks synthesis, hydrogen production for fuel cells and possible conversion of the waste and difficult accessible resources of natural gas. It can be clathrate (methane hydrate), coal bed methane, post fermentation biogas, land fill and recently shale gas able to be converted into liquid fuels, chemicals easily transportable liquid products. 


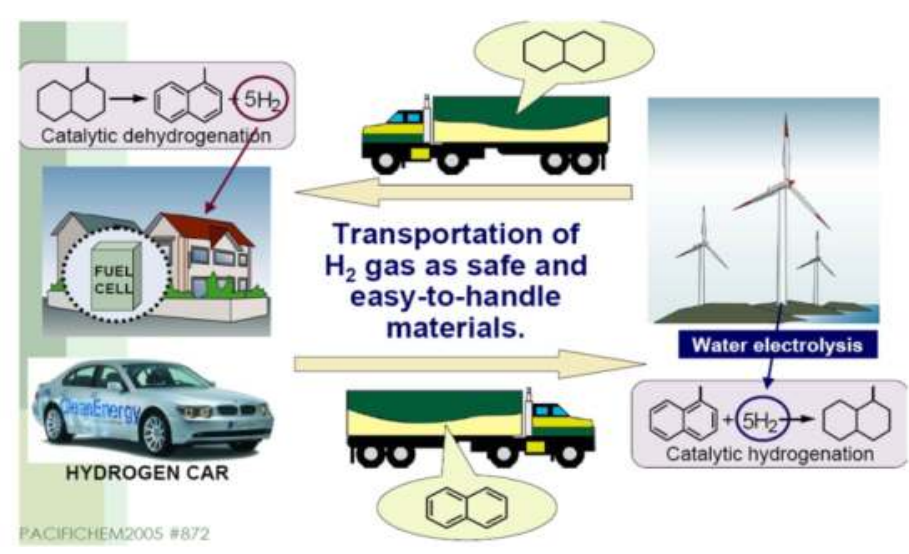

Figure 21. The idea of application LOH compounds as a hydrogen carrier (PACIFICHEM Conference 2005, \#872) [69]

\section{Environmental conditions for $x t L$ processes implementation}

"XtL" processes include an indirect path of energy generation from different types of biomass by converting it to liquid energy carriers [70]. XtL processes means "x to liquid fuels", that is the conversion of various types of raw materials as feedstock for liquid biofuels. The previously presented innovative technologies of waste carbon dioxide conversion and other forms of organic matter into liquid energy carriers are part of a convention of XtL processes.

The environmental aspects of $\mathrm{XtL}$ technologies are related with:

1. Emission to the atmosphere the additional amounts of GHG.

2. Generating, recycling and removal of waste.

3. The use of natural resources, raw materials and energy.

4. Sludge production.

5. Space planning (development of the new areas on the Earth).

6. Impact on biodiversity.

7. The destruction of animal species and their habitats.

These methods are directed to the reuse, recycling of existing $\mathrm{CO}_{2}$ for its processing into useful forms of energy. Algae used for production of liquid fuels are characterized by an effective reduction of significant amount of wastewater, through their purification from toxic substances such as heavy metals. The result of this microorganisms activity are the extra amounts of clean drinking water. It also shows that they have no negative impacts for ecosystems biodiversity, there are also not the reason of the disappearance of certain group of animals or plants. 
As it is clear from the review of literature, cultivation of algae for fuels production, seems to be a forward-looking technology for producing liquid energy carriers. The algae have many important advantages from the environmental point of view:

- they are able to sequester waste carbon dioxide, which is used for production of oil and sugars, that are a substrate for the biofuels production,

- they have the ability to bioremediation of contaminated environments,

- they create a "biofertilizers" by absorbing elements such as nitrogen and phosphorus,

- they do not compete with the food market,

- they have a greater oil production capacity than terrestrial energy plants (more than 10 times greater than cultivated oilseed crops),

- they are a group of organisms, with possibility of genetic changes for improvement of their production ability.

Concluding, it is clear from the above considerations, the discussed projects may be an excellent alternative to conventional resources of crude oil, gas and coal. Finally by reducing the concentration of carbon dioxide in the atmosphere, without any negative impact on the environment, above projects have large potential for limitation so-called Global Warming.

\section{SWOT analysis of selected technologies}

\subsection{Technology of "Artificial leaf"}

\section{STRENGTHS}

- The artificial leaf is able to carry out the water hydrolysis efficiently comparing with green plants.

- Artificial leaf is able to carry out the water hydrolysis process according to the reaction: $\mathrm{H}_{2} \mathrm{O} \rightarrow \mathrm{O}_{2}+2 \mathrm{H}_{2}$ producing hydrogen from noncarbon materials. Its combustion release pure drinking water and oxygen as a byproduct.

- Technology does not generate extra amounts of waste. must first be improved earlier.

- This method uses the solar energy.

- It uses an innovative catalyst to accelerate the reaction,

using common metals - nickel and cobalt.

- Developed artificial leaf does not need large areas to

be used - it has the size of a playing card, in addition, it is

very thin and light.

\section{WEAKNESSES}

- Artificial leaf is still not able to bind residual carbon dioxide. Research work on copying the entire process of photosynthesis, which takes place in green plants are still under development. The effective method of $\mathrm{CO}_{2}$ sequestration has not been invented yet. - To effectively trigger the energy, artificial leaf requires integration with existing fuel cells and solar panels, which 


\footnotetext{
- Developed process of artificial photosynthesis does not require cleaning of water. This technology would be able to use water from rivers, polluted postproduction water, pretreated wastewater, or even seawater to produce hydrogen as a fuel. Conversion of salty seawater resources to fresh drinking water can be one of most desired applicationt of this process.

- This technology will be used as a cheap source of electricity for households. An opportunity is a vision to use this method to produce the electricity also in the villages of India, or Africa.
}

\section{Table 7.}

The strength of "artificial leaf" is ability to carry out the hydrolysis process of water molecule into oxygen and hydrogen, which is the cleanest known fuel. It cannot be possibly limited in future only for use pure water but also polluted one. In this way, perhaps in the future could be used even salty water. Another strong point of this method is the efficiency of the artificial leaf, which now comes to (20... 30)\%. If Artificial Leaf would be able to bind waste carbon dioxide from the exhausted gases then it can be an effective method of producing so-called solarfuels.

\subsection{Methanol synthesis in carbon dioxide photoreduction process}

\begin{tabular}{|c|c|}
\hline STRENGTHS & WEAKNESSES \\
\hline $\begin{array}{l}\text { - High quality of biofuel gained in EtL process, meets } \\
\text { requirements for liquid fuels. } \\
\text { - Long lifetime of the catalyst estimated at 4-5 days. }\end{array}$ & $\begin{array}{l}\text { - Lack of direct } \mathrm{CO}_{2} \text { sequestration. } \\
\text { - Risk of catalyst sintering - no temperature control over the } \\
\text { entire height of the reactor. } \\
\text { - Low efficiency of the process }\end{array}$ \\
\hline OPPORTUNITIES & THREATS \\
\hline \multicolumn{2}{|c|}{ - The opportunity will be to further research funding and $\bullet$ Lack of research funding. } \\
\hline \multicolumn{2}{|c|}{$\begin{array}{l}\text { - Methods for producing second-generation biofuels are material for the biofuels production in the ETL process. } \\
\text { more likely for industrial implementation, because they }\end{array}$} \\
\hline \multicolumn{2}{|l|}{ are more technologically advanced than third generation } \\
\hline \multicolumn{2}{|l|}{ biofuels. } \\
\hline \multicolumn{2}{|l|}{ - These fuels are compatible with existing infrastructure } \\
\hline \multicolumn{2}{|l|}{$\begin{array}{l}\text { - Start of cooperation with institutions leading the } \\
\text { projects/ installations for the production of ethanol from }\end{array}$} \\
\hline waste biomass. & \\
\hline
\end{tabular}

Table 8. 
The opportunity for the development of EtL processes is a partnership with institutions leading the projects of ethanol production of all kinds of waste material.

\subsection{The process of photosynthesis without sunlight}

\section{STRENGTHS}

\section{WEAKNESSES}

- The use of genetic engineering to increase the productivity of breeding strains of algae.

- Production of a wide range of products from oils derived from algae. Besides the basic scope products such as fuel, among others biodiesel, aviation biofuel, biofuel for ships, Solazyme also produces various types of coproducts such as cosmetics, bioplastics, and animal feed.

- The biggest advantage of technology developed by Solazyme is its industrial implementation. There are already commercial biofuel production using this method and are known early success such as an American United aircraft passenger flight from Houston to Chicago powered by blend of $40 \%$ biofuel jet. This fuel has been certified by ASTM.

\section{OPPORTUNITIES}

\section{THREATS}

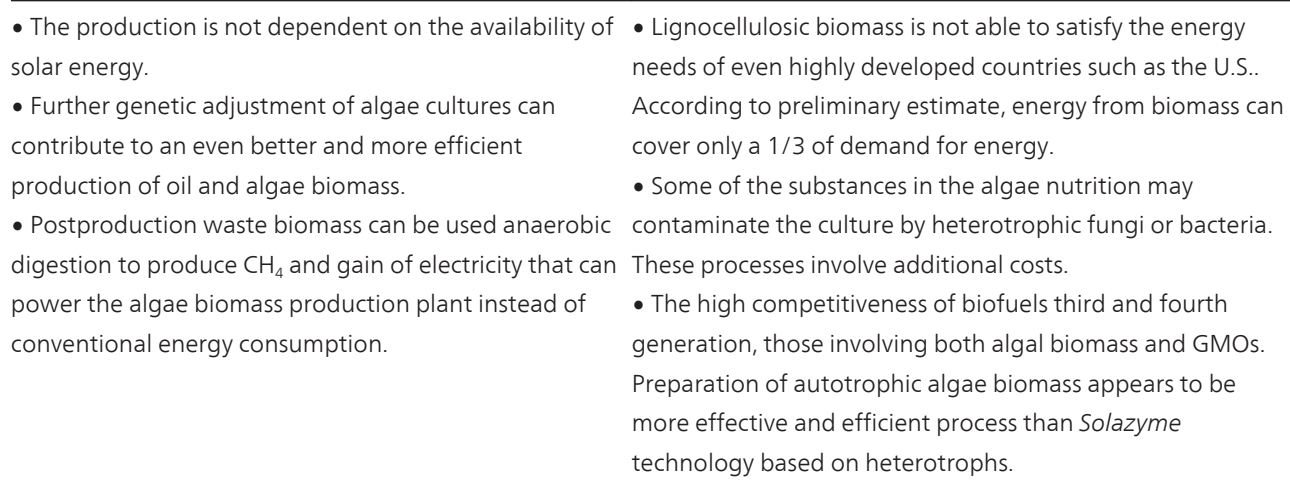

\section{Table 9.}

The advantage of sunless photosynthesis is the genetic modification of the strains cultivated algae. Genetic engineering allows increasing of algae productivity, and efficient development of microbial species without the solar energy. This in turn results in the elimination of risks in the form of competition from autotrophic algae. 


\subsection{OMEGA system - Marine membrane algae cultivation farms}

\section{STRENGTHS}

\section{WEAKNESSES}

- Autotrophic algae are cultivated which are even thirty • Localization issues - society is not prepared for existence of times more efficient in the oil production than algae farm in vicinity for example bays. oleaginous plants.

- OMEGA method involves activity on a large-scale, and not

- The fed raw material for algae is waste water from developed any alternative for smaller projects.

which algae receive essential nutrients, such as nitrogen or phosphorus.

- Used in the method of OMEGA algae are able to bind waste $\mathrm{CO}_{2}$ coming directly from the flue gas include plants and directly from the air.

- The duration of the production cycle last only

10-14days.

- Algae cultured in membrane systems are freshwater species that under conditions of salt are not able to survive. This means that in the event of a system failure will not spread microorganisms and does not attack the existing ecosystems. What's more, algae, which escapes from "farm" will be able to provide an extra source of food for fish, and the rest will be biodegradable, does not cause any pollution of the sea, or ocean. So it is a safe technology for natural ecosystems.

- Do not compete cultivation land area, because they can be grown in the desert, wasteland, or on the seas and oceans.

\section{OPPORTUNITIES}

THREATS

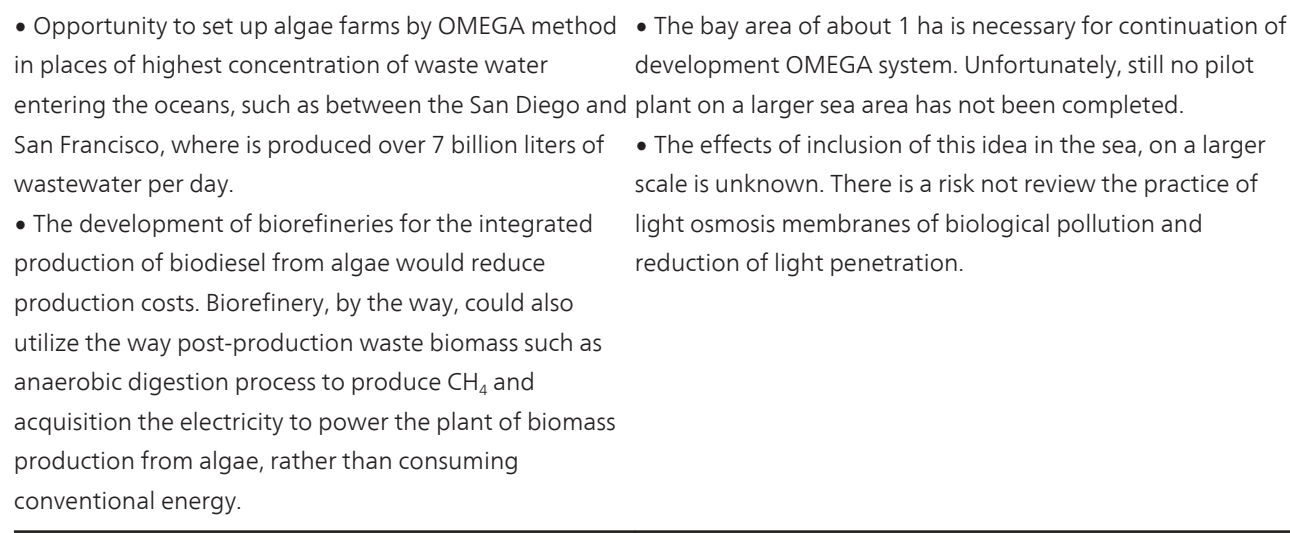

Table 10. 
Strong side of OMEGA system is the raw material for fed of algae. This allows to use the opportunity that comes from the cultivation of algae for example, between San Diego and San Francisco, where is discharged from industrial plants about 7 billion gallons per day of sewage into the sea. This would be a very effective method of disposing of waste, and even that would be a form of recycling, as a result of microbial activity would arise alternative fuels.

\section{Conclusions}

Cultivation of oil plants for fuels production creates strong competition with crops for consumption. It's hard to talk about the promotion of biofuels, which production is based on energy crops and in many cases is a major cause of the food crops shortage. In many regions of the World are starving societies of so-called third world countries. Therefore as the most desirable features of technology is to use waste $\mathrm{CO}_{2}$ to produce liquid fuels related with:

- reality;

- affordability;

- efficiency;

- the environmental aspect.

In addition, all products and waste that may be generated during the manufacturing process for liquid energy carriers, should use the strategy 3R-Recycling Reduce Reuse in order to reduce energy costs and protect the environment. It is believed that the process of hydrolysis of water by solar energy, in the artificial leaf technology, occurs and is energy efficient.

Harry B. Gray, winner of many awards, including in chemistry, in an article on "Solar Fuel" says:

„We need to stop burning hydrocarbon as soon as it is possible, because they are wonderful resources that we desperately need for the production of dyes, pharmaceuticals, T-shirts, chairs and cars - is irresponsible to burn them!"[71].

Waste Carbon dioxide is appropriate material. It is a resource that exists in plenty and causing a negative impact on the environment by including contributing to the greenhouse effect. Artificial photosynthesis is in the research phase and need more decades to make it economically profitable. Today we can see many successful trials to transform $\mathrm{CO}_{2}$ into various liquid fuel.

The presented analysis shows, that the most important goals for the energy sector should be utilization of carbon dioxide emissions by mentioned CCU idea. This target can be realized by using modern technology of $\mathrm{CO}_{2}$ reuse to produce liquid energy carriers. 


\section{Acknowledgements}

The authors gratefully acknowledge financial support from the EKOBENZ Ltd

\section{Author details}

Krzysztof Biernat ${ }^{1}$, Artur Malinowski ${ }^{1}$ and Malwina Gnat ${ }^{2}$

1 Automotive Industry Institute, Department for Fuels and Renewable Energy, Warsaw, Poland

2 Institute for Ecology and Bioethics, University Cardinal Stefan Wyszynski, Warsaw, Poland

\section{References}

[1] What the Future Holds in Store, in: World Climate Report, The Web's Longest-Running Climate Change Blog, 30 January, 2008, available from: http://www.worldclimatereport.com/index.php/2008/01/30/what-the-future-holds-in-store/ (accessed 20 August 2012)

[2] $\mathrm{CO}_{2}$ emissions from fuel combustion IEA Statistics, available from: http://www.iea.org/ co2highlights/CO2highlights.pdf (accessed 12 October 2011)

[3] W jaki sposób świeci Słońce?, available from: http://urania.pta.edu.pl/bahcall1.html dn. 12.12.2011 (accessed 25 October 2011) ( "How does the Sun shines?")

[4] Van Loon G., Duffy S. J., Gazy cieplarniane związane ze stosowaniem paliw opartych na węglu; Bilans energetyczny; Chemia klimatu globalnego, in Chemia środowiska, Pub. PWN SA, Warsaw, 2007. (Greenhouse gases associated with the use of carbon based fuels; The energy balance; Chemistry of the global climate, in Environmental chemistry)

[5] Solar energy distribution graph showing that infrared radiation makes up a large portion of the solar spectrum, available from: http://continuingeducation.construction.com/article.php? $\mathrm{L}=68 \& \mathrm{C}=488 \& \mathrm{P}=6$ (accessed 24 October 2012)

[6] Solar Spectrum, from Wikipedia, the free encyclopedia, available from: http://en.wikipedia.org/wiki/File:Solar_Spectrum.png (accessed 24 April 2012)

[7] Płaska J., Sałek M., Surma T., Wykład pierwszy. Charakterystyka odnawialnych źródeł energii, „Energetyka” - March 2005. („,The first lecture. Characteristics of renewable sources of energy")

[8] Strebeyko P., Fotosynteza, Pub. PWN, Warsaw, 1964. ("Photosynthesis") 
[9] Staroń K., (ed.) Przetwarzanie energii i materii podczas fotosyntezy, in Biologia, Pub. WSiP, Warsaw, 2003, ISBN 83-02-08628-2) pp. 106-120. (“The processing of energy and matter during photosynthesis in Biology")

[10] Luminos output of grow lights is not the right parameter, available from: http:// www.myledlightingguide.com/Article.aspx?ArticleID=39 (accessed 24 April 2012)

[11] Burda K., Dlaczego warto zajmować się fotosyntezą?, FOTON 93, Summer 2006, available from: http://www.if.uj.edu.pl/Foton/93/pdf/04\%20fotosynteza.pdf (accessed 20 September 2012) („,Why is photosynthesis?”)

[12] Directive 2009/29/EC, available from: http://eur-lex.europa.eu/LexUriServ/LexUriServ.do?uri=OJ:L:2009:140:0016:0062:pl:PDF (accessed 12 October 2011)

[13] Beret-Kowalska G., Kacprowska J., et al., Energia ze źródeł odnawialnych w 2007 roku, Information and Statistical Papers, Central Statistical Office, Department of Industry, Ministry of Economy, Department of Energy, Warsaw, 2008, pp. 5-14. (ISSN: 1898-4347) ("Energy from renewable sources in 2007")

[14] Grzybek A., Analiza możliwości wykorzystania surowców rolnych na potrzeby produkcji biopaliw, „Problemy inżynierii Rolniczej”, No. 1/2007. („Analysis of agricultural raw materials for the production of biofuels")

[15] Grzybek A., Zapotrzebowanie na biomasę i strategie energetycznego jej wykorzystania, „Studies and reports IUNG - PIB”, Issue II, 2008, Warsaw.) („The demand for biomass energy and its utilization strategies")

[16] Lipski R., Orliński S., Tokarski M., Energetyczne wykorzystanie biomasy na przykładzie kotłowni opalanej słomą we Fromborku, MOTROL, 2006, 8A, pp. 202-209. (“Energy use of biomass on an example of straw-fired boiler in Frombork")

[17] Roszkowski A., Efektywność energetyczna różnych sposobów produkcji i wykorzystania biomasy, the Institute for Building, Mechanization and Electrification of Agriculture, Warsaw, Studies and Reports IUN, issue 11/2008, available from: http:// 217.113.158.23/wydawnictwa/Pliki/pdfPIB/zesz11.pdf\#page=100 (accessed 12 April 2012) („The effectiveness of different methods of biomass production and use")

[18] Biopaliwa - ratunek dla klimatu czy zagrożenie dla przyrody, Warsaw, 5 April 2011, OTOP, available from: http://otop.org.pl/uploads/media/informacja_prasowa_biopaliwa.pdf (accessed 23 March 2012) („Biofuels - the rescue of the climate or the threat to wildlife?")

[19] Wójcicki Z., Energia odnawialna, biopaliwa i ekologia, IBMiER in Warsaw, „Problemy Inżynierii Rolniczej” No. 2/2007. ("Renewable energy, biofuels and ecology")

[20] Niedziółka I., Zuchniarz A., Analiza energetyczna wybranych rodzajów biomasy pochodzenia roślinnego, Department of Agricultural Machinery, Agricultural University of Lublin, „MOTROL”, 2006, 8A, pp.233, available form: http://www.pan-ol.lublin.pl/wydawnictwa/Motrol8a/Niedziolka.pdf (accessed 23 April 2012) ("Energy analysis of selected types of plant biomass") 
[21] Kijeńska M., Kijeński J., Biopaliwa czy wyczerpaliśmy już wszystkie możliwości?, "CHEMIK", 2011, available from: http://chemia.wnp.pl/biopaliwa-czy-wyczerpalismy-juz-wszystkie-mozliwosci,7511_2_0_2.html (accessed 22 October 2011) („Biofuels - did we exhauste all the possibilities?")

[22] Taylor K., Ivanovsky W., Spirits mixture of diesel, "Chemical Industry" No. 11-12, Lvov, Poland, 1926

[23] http://ec.europa.eu/clima/policies/roadmap/index_en.htm (accessed 09 October 2012)

[24] Technology Roadmap Biofuels for Transport (C) OECD/IEA, 2011, International Energy Agency 9 rue de la Fédération 75739 Paris Cedex 15, France

[25] Bosmans A., Vanderreydt I., Geysen D., Helsen L., The crucial role of Waste-to-Energy technologies in enhanced landfill mining: a technology review, Journal of Cleaner Production. In press. Available from: http://www.sciencedirect.com/science/article/pii/ S0959652612002557(accessed 19 September 2012)

[26] Naber J. E., Goudriaan F., (BIOFUEL BV), Successfully using biomass to Harness renewable energy in an efficient and cost-effective way, available from: https:// docs.google.com/viewer?a=v\&q=cache:_SpnMHqVSawJ:www.cpi.umist.ac.uk/ eminent/Confidential/meeting/RigaMeeting/Riga\%2520Workshop/PresenatieHTUBiofuel.ppt+\&hl=en\&gl=pl\&pid=bl\&srcid=ADGEESgMHqR-

XurQxLkzf8s6voe2T2AsmrxLMOGwHrqmqRYlcUMMekL57T8pTeLtMDgxMN6dLSYz30U37W5gpDoAKfAISwapjspGTUrVB9XwICS5SkcnnJ0uka5wr wNfz6AD27qedYLa\&sig=AHIEtbTXFACuXwfDtR9YJho3R2xu1V8VTw (accessed 9 September 2012)

[27] Li G., Kong L., Wang H., Huang J., Xu J., Application of hydrothermal reaction in resource recovery of organic wastes, State Key Lab of Pollution Control and Resource Reuse, School of Environmental Science and Engineering, Tongji University, No. 1239 Siping Road, Shanghai 200092, China

[28] Malinowski A., Perspektywiczne technologie biopaliw drugiej generacji na rynku europejskim, conference: „Rynek biopaliw w unijnym pakiecie dot. energii i klimatu”, Warsaw, 27 September 2010 („Promising second-generation biofuels technologies in the European market")

[29] Official website of Alphakat Diesel: http://www.alphakatdiesel.pl/technologiakdv.html (accessed 19 April 2012)

[30] Technology modules of KDV, available from: http://www.kdv-projektmanagement.com/technology (accessed 19 April 2012)

[31] Official website of AlphakatPoland: http://alphakatpolska.pl/char_pro.html (accessed 19 April 2012)

[32] Official website of JCAP: http://solarfuelshub.org/hub-overview 
[33] PL Patent 208030 B1, „Katalizator do syntezy metanolu i jego pochodnych” by Nazimek D., Czech B., Jabłoński B., Zaniuk W., Wasińska Z. ("The catalyst for the synthesis of methanol and its derivatives").

[34] Nazimek D., (2009) Sztuczna Fotosynteza $\mathrm{CO}_{2}$ - pierwszy etap produkcji biopaliw, available from: http://www.gmina.zgierz.pl/cms/files/File/KONFERENCJA\%20Rogozno\%20-\%20wczoraj,\%20dzis, \%20jutro/SFCO2-2009-Krakow.pdf

("Artificial Photosynthesis CO2 - the first stage in the production of biofuels").

[35] Report: Polish Power Plant and University to Cooperate on CO2 to Methanol Trial, available from: http://www.greencarcongress.com/2009/07/nazimek-20090707.html (accessed 21 April 2012)

[36] Nazimek D., Niećko J., (2010) Coupling Ethanol with Synthetic Fuel, Polish J. of Environ. Stud. Vol. 19, No. 3 (2010), 507-514, available from: http:// www.pjoes.com/pdf/19.3/507-514.pdf (accessed 20 September 2012)

[37] MIT's Daniel Nocera Announces Artificial Leaf With Goal To Make Every Home a Power Station, Signs with Tata, available from: http://www.freeenergytimes.com/ 2011/03/28/mit-chemist-daniel-nocera-announces-artificial-leaf-goal-to-make-everyhome-a-power-station/ (accessed 10 May 2012)

[38] Van Noorden R., Secrets of artificial leaf revealed, Nature, doi:10.1038/news.2011.564, published online 29 September 2011, available from: http://www.nature.com/news/ 2011/110929/full/news.2011.564.html (accessed 10 May 2012)

[39] Chandler D. L., Taking a Leaf from Nature's Book, Technology Review published by MIT, January/February 2012, available from: http://www.technologyreview.com/ printer_friendly_article.aspx?id=39259 (accessed 24 April 2012)

[40] Regalado A., „Reinventing the Leaf. The ultimate fuel may come not from corn or algae but directly from sun itself.", „Scientific American”, October 2010, pp.68-71.

[41] Prototype reactor uses the sun to generate storable hydrogen fuel, available from: http://www.mobilemag.com/2010/12/28/prototype-reactor-uses-the-sun-to-generatestorable-hydrogen-fuel/ (accessed 24 April 2012)

[42] Chueh W. C., Falter C., Abbott M., Scipio D., Furler P., Haile S. M., Steinfeld A., HighFlux Solar-Driven Thermochemical Dissociation of CO2 and H2O Using Nonstoichiometric Ceria, „Science”, 24.12.2010.: Vol. 330 No. 6012 pp.1797-1801.

[43] Scott S. A., Biodiesel from alga: challenges and prospects, „ScienceDirect”, Current Opinion in Biotechnology 2010,21:277-286.

[44] Fishman D., Majumdar R., Morello J., Pate R., National Algal Biofuels Technology Roadmap, U.S. Department of Energy, Office of Energy Efficiency and Renewable Energy, Biomass Program, U.S. DOE 2010. 
[45] Burczyk B., Biomasa. Surowiec do syntez chemicznych i produkcji paliw, OWPW, Wrocław 2011, pp.180,244. („Biomass. Raw material for the chemical synthesis and the production of fuels")

[46] Frąc M., et al, Algi - energia jutra (biomasa, biodiesel), Acta Agrophysica 2009, 13(3), 627-638, Instytut Agrofizyki im. Bohdana Dobrzańskiego PAN, Lublin, pp.634. („Algae - tomorrow's energy (biomass, biodiesel")

[47] Zakrzewski T., Biomasa mikroalg-obiecujące paliwo przyszłości, "Czysta Energia”, 2/2011(114). ("Biomass microalgae-promising fuel of the future", "Clean Energy")

[48] Kozieł W., Włodarczyk T., Glony-produkcja biomasy, Acta Agrophysica 2011, 17(1), 105-116, Instytut Agrofizyki im. Bohdana Dobrzańskiego PAN, Lublin, pp. 109. (,Algae-biomass production”)

[49] Cieśliński H., Biodiesel z alg - paliwo przyszłości?, available from: http://www.silawiedzy.pl/images/stories/artykuly_pdf/837.pdf (accessed 12 April 2012) (“Biodiesel from algae - fuel of the future?")

[50] Sapphire Energy technology, available from: http://www.sapphireenergy.com (accessed 11 April 2012)

[51] Malinowski A., Biopaliwa dla Lotnictwa (Aviation Biofuels), Czysta Energia (Clean Energy), Nr: 121, 9/2011; http://e-czytelnia.abrys.pl/index.php?mod=tekst\&id=13518 (accessed 08 October 2012)

[52] Algenol's carbon platform modular technology, available from: http://www.algenolbiofuels.com/direct-to-ethanol/direct-to-ethanol (accessed 23 April 2012)

[53] OMEGA, in AlgaeSystems, available from: http://algaesystems.com/technology/ omega/ (accessed 24 April 2012)

[54] Schwartz D., AIM Interview: NASA's OMEGA Scientist, Dr. Jonathan Trent, August 21, 2011in Algae Industry Magazine website, available from: http://www.algaeindustrymagazine.com/nasas-omega-scientist-dr-jonathan-trent/ (accessed 24 April 2012)

[55] Trent J., Wiley P., Tozzi S., McKuin B., Reinsch S., Biofuels, Volume 3, Issue 5, The future of biofuels: is it in the bag?, pp. 521-524, 01 September, 2012

[56] Sikora Z., Heterotroficzny wzrost glonów, „Wiadomości Botaniczne”, Volume XIII Issue 2, 1969. ("Heterotrophic growth of algae")

[57] Gunther M., Solazyme's amazing algae, available from: http://www.marcgunther.com/ 2010/03/18/solazymes-amazing-algae/ (accessed 11 April 2012)

[58] Fuel from algae, available from: www.technologyrewiev (accessed 24 August 2011)

[59] U.S. Navy Successfully Tests SoladieselHRD-76® During Operational Transit Voyage in USS Ford Frigate, Solazyme Inc., March 13, 2012, available from: http://investors.solazyme.com/releasedetail.cfm?ReleaseID=656801 (accessed 13 March 2012) 
[60] Ohnishi R., Liu S., Dong Q., Wang L., Ichikawa M., Catalytic Dehydrocondensation of Methane with $\mathrm{CO}$ and $\mathrm{CO}_{2}$ toward Benzene and Naphthalene on Mo/HZSM-5 and Fe/ Co-Modified Mo/HZSM-5, J. Catal. 182, 92 (1999).

[61] Shu Y., Ma H., Ohnishi R. and Ichikawa M., Highly stable performance of catalytic methane dehydrocondensation towards benzene on Mo/HZSM-5 by a periodic switching treatment with $\mathrm{H}_{2}$ and $\mathrm{CO}_{2}$, Chem. Commun., 86, (2003).

[62] Malinowski A., Ohnishi R., Ichikawa M., CVD Synthesis in Static Mode of Mo/H-ZSM5 Catalyst for the Methane Dehydroaromatization Reaction to Benzene, Catalysis Letters Vol.96, No 3-4, pp 141-146, (2004)

[63] Patent JP2002336704 Japan Steel Works LTD, Aromatizing reaction catalyst of methane and method for preparing the same, 26 Nov. 2002, Ichikawa M., Ohnishi R., Malinowski A.,. Ikeda K., Yagi K.; The European Patent Office: http://ep.espacenet.com

[64] Shu Y., Xu Y., Wong S., Wang L., Guo X., Promotional Effect of Ru on the Dehydrogenation and Aromatization of Methane in the Absence of Oxygen over Mo/HZSM-5 Catalysts, J. Catal. 17011 (1997).

[65] Weckhuysen B.M., Wang D., Rosynek M.P., and Lunsford J.H., Conversion of Methane to Benzene over Transition Metal Ion ZSM-5 Zeolites: II. Catalyst Characterization by X-Ray Photoelectron Spectroscopy ,J. Catal. 175, 347 (1998).

[66] Wang D., Lunsford J.H., Rosynek M.P., Characterization of a Mo/ZSM-5 Catalyst for the Conversion of Methane to Benzene, J. Catal. 169347 (1997).

[67] Solymosi F., Cserényi J., Szöke A., Bánsagi T., and Oszkó A. J., Aromatization of Methane over Supported and Unsupported Mo-Based Catalysts ,J. Catal. 165, 150 (1997).

[68] Liu Z., Nutt M.A. and Iglesia E., The Effects of $\mathrm{CO}_{2}, \mathrm{CO}$ and $\mathrm{H}_{2}$ Co-Reactants on Methane Reactions Catalyzed by Mo/H-ZSM-5, Catal. Lett., 2002, 81, 271-279.

[69] PACIFICHEM Conference 2005, \#872

[70] Biernat K., Biokomponenty i biopaliwa - możliwości rozwoju i zastosowania, „Forum Czystej Energii” X edycja, 23-25 listopada 2010 r., Poznań, „Technology Roadmap. Biofuels for Transport” Pub. OECE/IEA, Paris 2011. („Biocomponents and biofuels opportunities for development and use")

[71] Gray, H. B., Solar Fuel, „Engineering and Science” 60 (3). pp. 28-33, 1997, ISSN 0013-7812, available from: http://calteches.library.caltech.edu/3924/1/Fuel.pdf (accessed 20 September 2012) 